How to cite this work: Orellana Macías, J.M., \& Perles Roselló, M. ${ }^{a}$ J. (2020). A comparative analysis of methods for mapping groundwater pollution hazard: application to the Gallocanta Hydrogeologic Unit (Spain). Boletín de la Asociación de Geógrafos Españoles, 85, 2885, 1-42. https://doi.org/10.21138/bage.2885

\title{
A comparative analysis of methods for mapping groundwater pollution hazard: application to the Gallocanta Hydrogeologic Unit (Spain)
}

Análisis comparado de métodos para la cartografía del peligro de contaminación de aguas subterráneas:

aplicación a la Unidad Hidrogeológica de Gallocanta (España)

\author{
José María Orellana Macías \\ jm.orellana@igme.es \\ Instituto Geológico y Minero de España \\ María Jesús Perles Roselló \\ mjperles@uma.es \\ Departamento de Geografía \\ Universidad de Málaga (España)
}

\begin{abstract}
Anthropogenic activities are the main sources of groundwater pollution. In order to prevent groundwater degradation and to apply suitable mitigation measures, hazard maps are a useful instrument for decision makers. The ultimate goal of the research is to analyse the effectiveness of several groundwater hazard indexes at the Gallocanta Lagoon Basin. To do so, the Hazard Index,
\end{abstract}


the Danger of Contamination Index and the Pollutant Origin and its Surcharge Hydraulically method were applied and compare, and the potentialities and weaknesses of the resulting maps have been analysed. Accurate hazard maps were obtained and, based on their methodological approach, significant differences were found in relation to the rating process, the inventory of the sources, and the treatment of quantity and likelihood. In the light of the results, the indexes tended to undervalue the hazard level of agricultural activities, which were the main sources of pollution of the study area. Therefore, due to the characteristic land uses of the study area, typical of the Mediterranean context, some proposals to improve the indexes have been suggested.

Key words: hazard index; aquifer pollution; cartography; hazard map; human contamination.

\section{Resumen}

Las actividades humanas son la principal fuente de contaminación de las aguas subterráneas. Para la prevención de su degradación y la aplicación de las medidas de mitigación apropiadas, los mapas de peligrosidad son una herramienta útil para los responsables de la toma de decisiones. El objetivo último del artículo es analizar la eficacia de índices para la elaboración de cartografías de peligrosidad de contaminación de acuíferos en el entorno de la Laguna de Gallocanta. Se han aplicado y comparado el Índice de Peligrosidad, el Índice de Peligro de Contaminación y el Método de Origen del Contaminante y su Carga Hidráulica, y se han analizado las potencialidades y limitaciones de la cartografía resultante. Se han obtenido mapas precisos, sin embargo, se han observado diferencias entre los índices debido a sus enfoques metodológicos, relacionadas con el proceso de puntuación de las actividades contaminantes, el inventariado de dichas actividades y el tratamiento de factores como la cantidad y la probabilidad. En base a los resultados obtenidos, los índices han mostrado tendencia a infravalorar el peligro de las actividades agrarias, las principales en la zona de estudio. Por lo tanto, dadas las características de los usos del suelo de la zona, propias del ámbito mediterráneo, se han realizado algunas propuestas de mejora de los índices.

Palabras clave: índice de peligrosidad; contaminación de acuíferos; cartografía; mapa de peligrosidad; contaminación humana.

\section{Introduction}

Groundwater is a key resource for human supply worldwide (Foster \& Chilton, 2003). Not in vain, at least $50 \%$ of the global population depends on it to satisfy their basic daily water needs 
(UNESCO, 2015), and this proportion increases to 75\% in the European Union (EU) (Vargas, 2018). In the last decades, the expansion of anthropogenic activities (i.e. agriculture, urbanization, industry, etc.) that use groundwater have considerably increase the pressure over these resources throughout the world (Cosgrove \& Rijsberman, 2000; Llamas \& Custodio, 2002; Foster et al., 2002; EASAC, 2010; UNESCO, 2015). Consequently, according to Gleeson et al. (2012), 20\% of the world's aquifers were over-exploited, and 38\% of the European water bodies were under agricultural pollution threat (UNESCO, 2015). The issue is even more threatening in the Mediterranean area, where the inter-annual and the intra-annual rainfall variations enhance the use of groundwater (Moreno et al., 2005), especially in the climate's change context, where more recurrent droughts and dry periods are expected (IPCC, 2018).

Anthropogenic pressures might last for a long time and they do not only increase pollutant concentrations, but also slow down the quantity and quality of the recovery rates. Once aquifers become polluted, contamination persists and it is difficult to remove it due to either their storage, long residence time or physical inaccessibility (Foster \& Chilton, 2003). In addition, monitoring and restoration of the aquifers is more difficult than in surface waters, and so it is pollution prevention (Vargas, 2018). However, prevention must be an essential component in groundwater management. Indeed, in the last years, hazard, vulnerability, and risk assessment studies have become one of the most useful tools for groundwater pollution prevention and control (Foster et al., 2002; Shrestha et al., 2016). The aim of these studies is to identify and delimit those areas that are prone to be polluted as a consequence of anthropogenic activities (Busico et al., 2017).

Groundwater pollution risk is defined as the probability that an adverse outcome occurs in a person or group of people as the consequence of a certain concentration of a hazardous agent from anthropogenic activities (Vías, 2005). Risk depends both on pollutants harmfulness and on the level of exposure (Daly et al., 2004). Therefore, in the context of groundwater pollution, a hazard is defined as a potential source of pollution resulting from human activities (Zwahlen et al., 2004). The role of the water resources and the environment regulator is to mount groundwater quality and quantity protection programs, which should include the delimitation of land-use zoning and the implementation of groundwater protection measures (Foster et al., 2002).

Groundwater deterioration can directly affect surface water bodies, wetlands, and protected areas. Therefore, in order to guarantee groundwater sustainability and to protect the good quality of the aquifers, water authorities have established laws for the groundwater's management and protection (Foster and Candela, 2007). Since the 1990s, the protection of groundwater has 
become in one of the most pressing objectives in the EU. The Nitrates Directive 91/676/EEC (ND) and the Urban Wastewater Treatment Directive 91/271/EEC (UWTD) aimed to protect, reduce, and prevent, water pollution caused by nitrates from agricultural sources, and by discharges from urban and industrial waste waters (EEC, 1991a; EEC 1991b). More recently, the Water Frame Directive 2000/60/CE (WFD) and, specifically, the Groundwater Directive 2006/118/EC (GWD) aimed to prevent and face groundwater pollution in the EU by limiting the discharges of pollutants into groundwater systems and by designing measures for the reversal of pollution trends (EC, 2000; EC, 2006). In this context, hazard maps at a proper scale are key instruments both for national and local authorities with responsibilities at the planning and decision-making level for (1) the assessment of groundwater pollution, and (2) the correct implementation of preventive and mitigating measures (Mimi \& Assi, 2009).

In the last decades, several authors have proposed approaches to evaluate and map pollution hazard (Johansson and Hirata, 2004). In the seventies, Mazurek published one of the first hazard indexes, the modification of the LeGrand method (Mazurek, 1979). In the next decade, Foster and Hirata proposed the Pollutant Origin Surcharge Hydraulically (POSH) method (Foster \& Hirata, 1988) at catchment scale, which was modified in 2002 (Foster et al., 2002). This method classified the pollutant according to their sources and their hydraulic surcharge. Already in the 1990s, Civita and Di Maio (1997) created the Danger Contamination Index (DCI), which was the result of the combination of the intrinsic hazard of different types of pollutants derived from anthropogenic activities.

In the framework of the WFD, the European Commission enhanced the COST Action 620. This scientific report included approaches for assessing and mapping groundwater vulnerability, hazard, and risk, in order to develop a consistent European approach for the protection of karst groundwater (Zwahlen et al., 2004). The COST Action 620 also proposed a method for rating and mapping existing and potential groundwater contamination sources, the so-called Hazard Index (De Ketelaere et al., 2004). In the COST Action project, the hazard mapping approach was applied and validated in karstic aquifers across Europe: in Spain (Andreo et al., 2004), Germany (Goldscheider et al., 2004), Austria (Cichocki et al., 2004) or Hungary (Mádl-Sz őnyi et al., 2004). In addition, this approach was widely implemented in other countries by many authors: Vías (2005) and Jiménez-Madrid et al. (2010) mapped hazards in karstic aquifers in southern Spain, Entezari et al. (2016) analysed risk in karst aquifers in Iran based on the HI methodology, and Kuisi et al. (2014) assessed groundwater vulnerability and hazard in an arid region in Jordan. Mimi and Assi (2009) also opted for the HI method for mapping groundwater 
hazard and risk in Palestina, whereas Hamamin et al. (2018) used it for mapping a water-bearing unit in Iraq. In addition, despite this method was specifically created for karstic aquifers, it was also successfully applied to groundwater bodies with different hydrogeological characteristics (e.g. Dimitriou et al. (2008) assessed pollution hazards in a heavily industrialised catchment in Greece, composed by carbonated and detritic aquifers, and Boulabeiz et al. (2019) mapped hazards sources as part of a risk analysis in a coastal Quaternary aquifer in Algeria).

The selection of the study area is justifiable, considering it is highly valuable from an ecological point of view. Not in vain, it has been declared as a Site of Community Interest, Special Protection Area for Birds, Ramsar wetland and Nature Reserve. In addition, from an economic perspective, intensive agriculture and livestock farming are the main activities and thus, the most relevant sources of employment. However, those activities are considerably pollutant and both ecological and agronomic contexts are dependent on the groundwater quality. Therefore, the identification and regulation of the potential sources of pollution need to be addressed urgently.

The groundwater pollution data collected in the area highlight that current protection measures related to the declaration of the study area as a Nitrate Vulnerable Zone in 1997 (Gobierno de Aragón, 1997) are insufficient. Following the Nitrate Directive (EEC, 1991a), several Action Programmes have been implemented in the last twenty years, but nitrate concentration is still higher than in 1997. Therefore, in the current climate change context, groundwater quality status may be expected to deteriorate if a different mitigation approach is not applied. Among the critics to the system of Nitrate Vulnerable Zones delimitation, it should be addressed that the term is misleading and that it does not take into account the spatial transportation of the pollutant on the surface nor in the aquifer. The system ignores two essential aspects of the groundwater pollution procedure: firstly, the spatial distribution of the sources of pollution, and secondly, the intrinsic vulnerability of the aquifer. Thus, the creation of a hazard map of the study area achieves an additional value as a tool for improving the pollution management in the area.

The ultimate goal of the research is to assess the efficiency of groundwater pollution hazard indexes widely accepted by the scientific community. To this end, three methods (the Hazard Index, the Danger Contamination Index and the Pollutant Origin Surcharge Hydraulically Index) have been applied. Based on a comparative method, the requirements, potentialities and weaknesses of the indexes at the Gallocanta Lagoon surroundings have been analysed. 


\subsection{Study area}

The study area covers the $540 \mathrm{~km}^{2}$ of the Gallocanta Lagoon catchment, an endorheic sub-basin included within the Gallocanta Hydrogeologic Unit (GHU) and located in the southern boundary of the Ebro Basin, in Spain (Figure 1). The climate is classified as Mediterranean semi-arid, due to the continental and altitudinal influence. The average annual precipitation for the period 19502018 was around $400 \mathrm{~mm}$, peaking in Spring and Autumn, whereas the average temperature is $11.6^{\circ} \mathrm{C}$. The elevation ranges from $990 \mathrm{~m}$ a.s.I. in the middle of the basin to up to $1400 \mathrm{~m}$ in the NE and SW boundaries. However, the mean slope is $4 \%$ and the morphology of the study area is basically flat in most of the catchment.

Figure 1. Gallocanta Basin topography and location

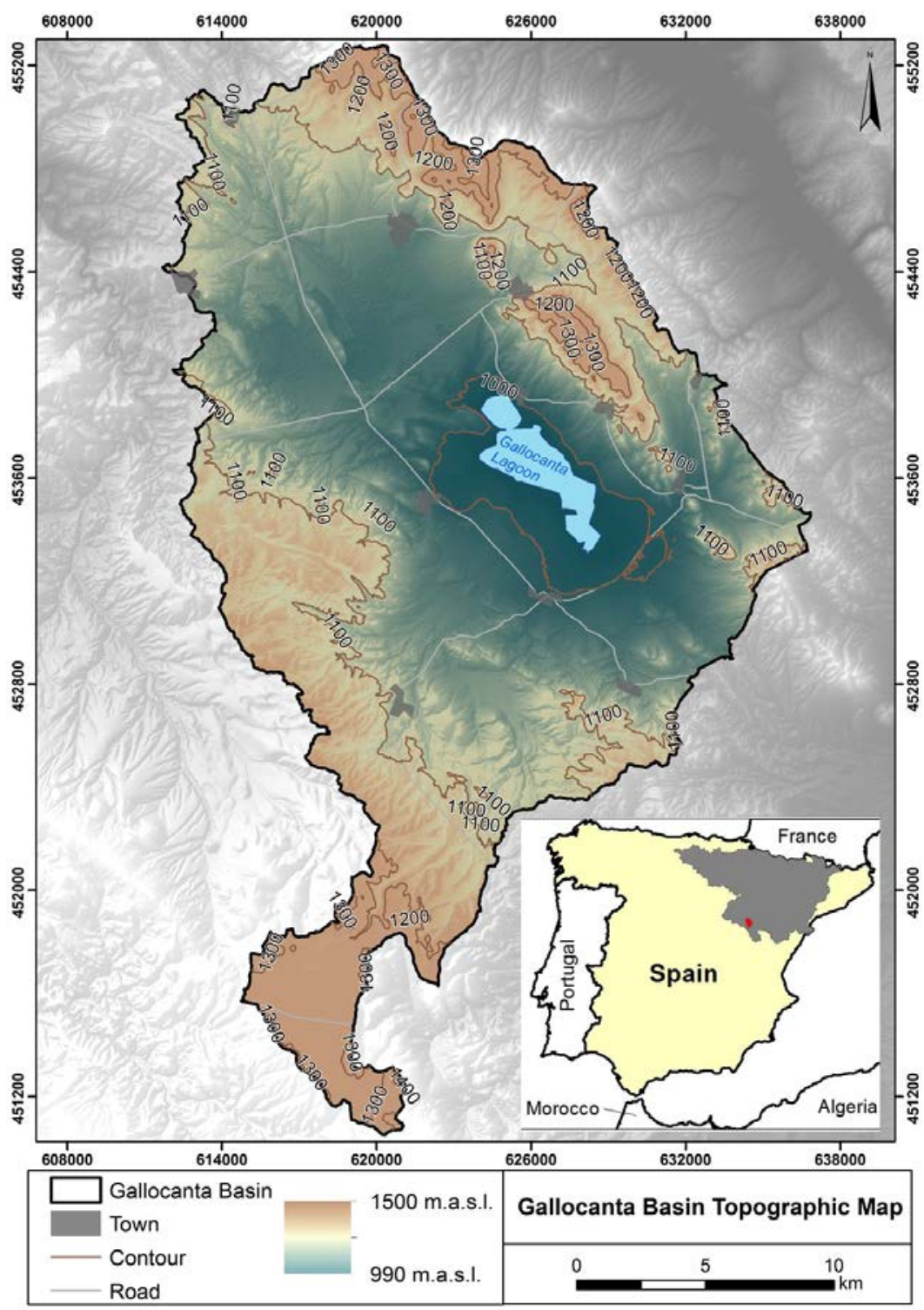

Source: own elaboration 
The GHU is a multilayer aquifer system (Figure 2), which includes at the eastern limit a Paleozoic aquifer with low permeability, an unconfined shallow Quaternary aquifer occupying the central and south areas of the basin, and several carbonated aquifers formed by rocks with different hydrogeological characteristics: sandy low permeable Triassic materials, and karstic Cretaceous and Jurassic limestones (CHE, 2003). The Triassic materials have low hydraulic conductivity and they are extended beneath the Quaternary sediments in the central area of the basin. The interaction between Quaternary and Triassic materials, mainly Keuper facies, prevents groundwater to leave the basin and facilitates the presence of the lagoon (Gracia et al. 1999). On the other hand, the Cretaceous and the Jurassic aquifers may be considered the most important aquifers of the area (CHE, 2016). Cretaceous and Jurassic rocks outcrop at large areas at north, west and south (Pérez et al. 2002), and from a hydrogeological point of view, both have similar characteristics. They directly feed the Quaternary aquifer at the central part of the basin and even the Jurassic is connected to the lagoon in its northwest shore. From a social perspective, both of them supply water for the human use in the central and western part of the basin.

Figure 2. Left: Geologic map of the Gallocanta Basin (Quaternary: silt, clay and gravel sediments; Cretaceous: limestone, dolomite, sandstone and loam; Jurassic: dolomite, carniola and loam; Triassic: clay, loam and sandstone; Paleozoic: quartzite, slate, clay and sandstone). Right: Land uses in the Gallocanta Basin

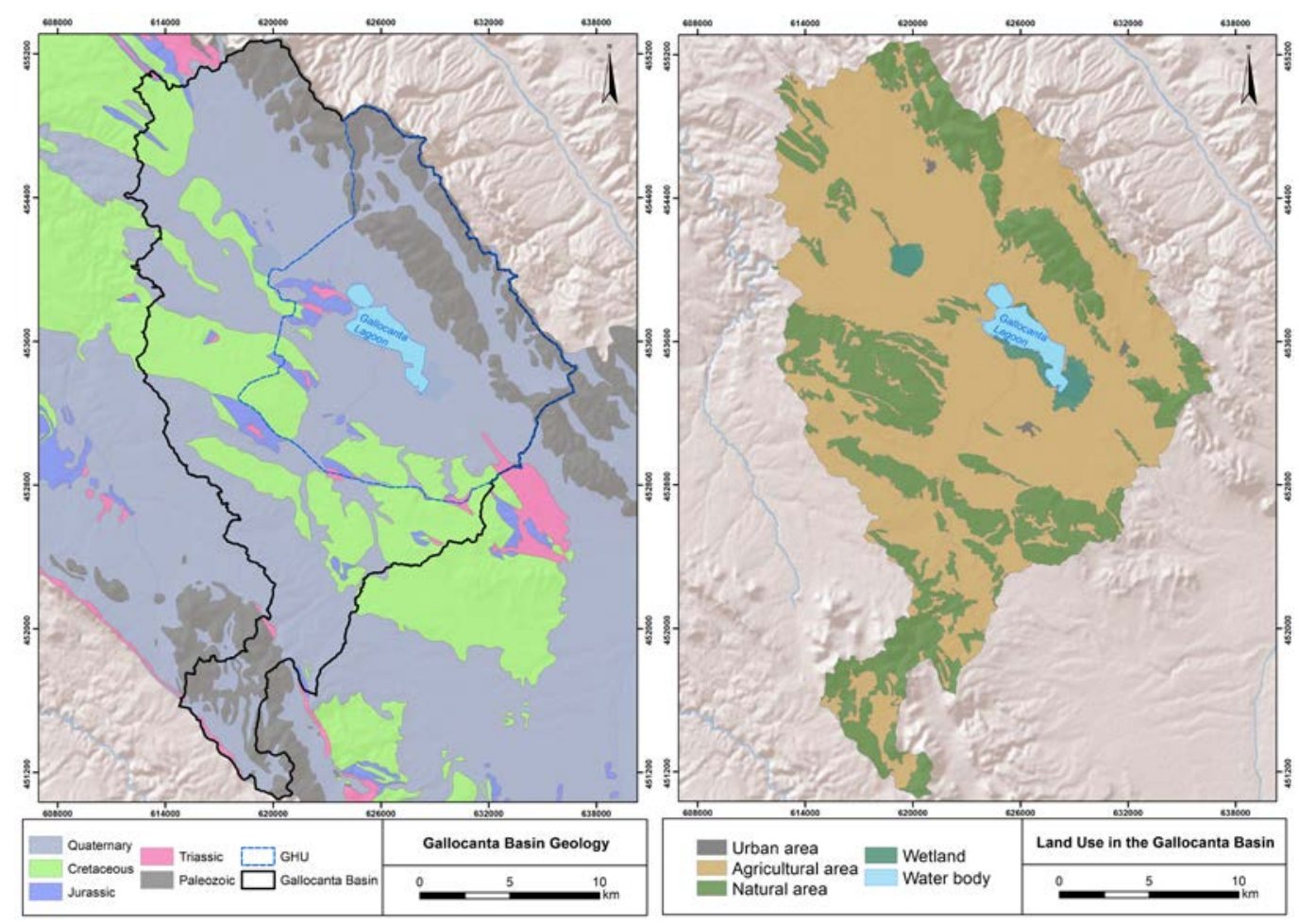

Sources: (Left) CHE; (right) CORINE Land Cover (2018) 
In this geological framework, the anthropogenic activity has created a typically rural landscape, the estimated population of the area is less than 2000 inhabitants, with small villages (population <300 inhabitants) and scattered settlements related to agriculture and livestock. According to the municipal census, the most populated villages in 2018 were Used (271 inhabitants), Bello (225 inhabitants) and Tornos (213 inhabitants).

According to the Spanish Cadastre (2018), the predominant land use in the study area is arable land (67\%), followed by natural or semi-natural areas (15\%), forests (14\%), and the lagoon and its surrounding wetland (3\%), whereas the extension occupied by urban or industrial sites is only $1 \%$ (Figure 2). Tertiary activities are marginal, and the road system is composed by regional roads and a dense network of tracks.

Figure 3. Agricultural water management

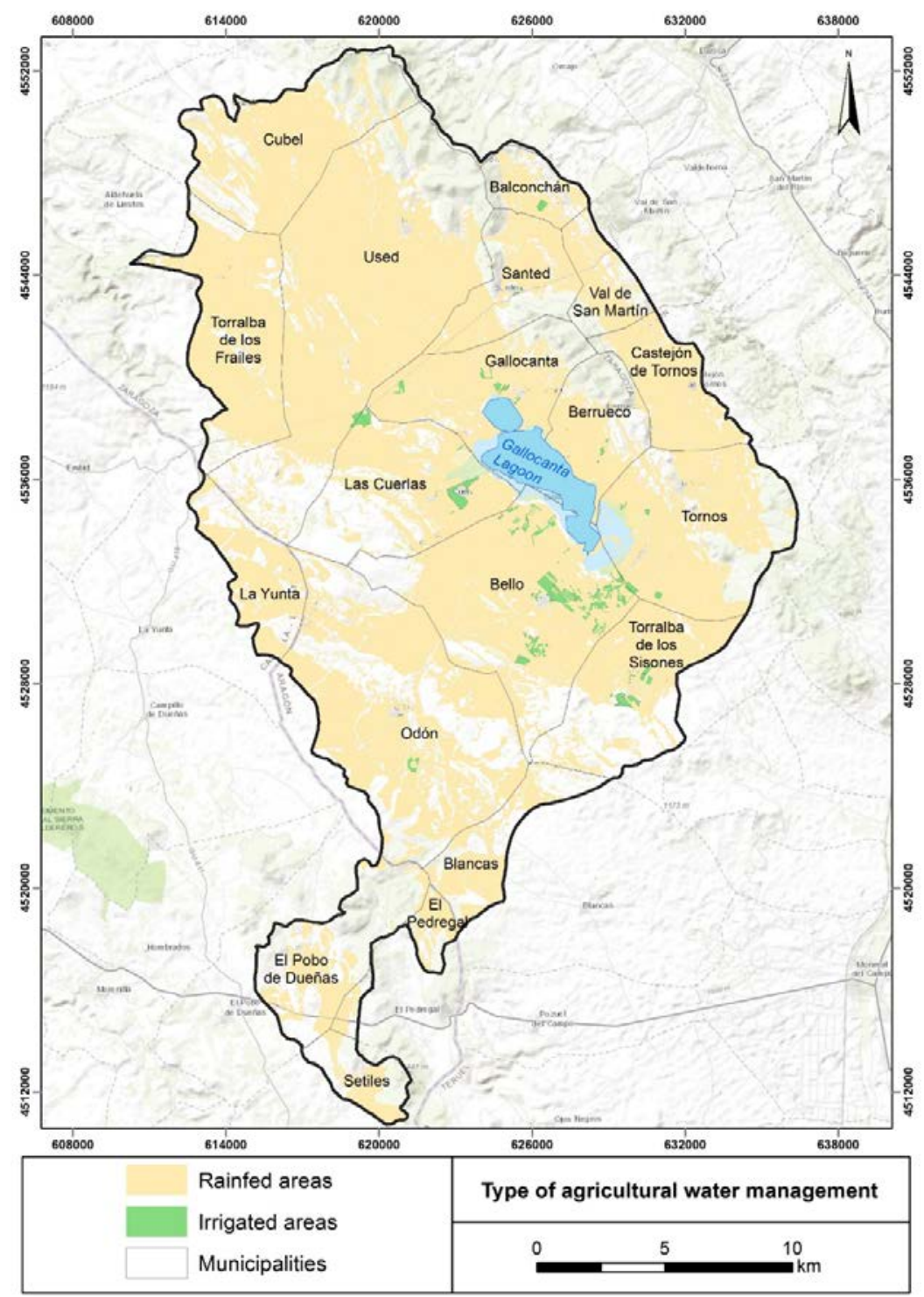

Source: own elaboration 
In conjunction with the arable land, urban and industrial uses are the main sources of potential pollutants, so to catalogue them is an indispensable first step for mapping hazards in the area. In the case of arable lands, most of them are industrialised rainfed crops, dedicated to wheat, barley, some almond trees and sunflowers. On the other hand, irrigation areas are basically devoted to wheat, barley and potatoes, and they occupy 450 ha in the south, west and north shores of the lagoon (Figure 3). In some plots, industrial monoculture of wheat and barley is combined with sunflowers both in irrigated and rainfed areas. Fertilization rates are adapted to the crop needs based on the potential harvest.

Undoubtedly, agricultural activities are the predominant source of pollution, especially nitrates, not only from arable lands, but also from factory farms. Most of them are pig, cattle and sheep farms. The total livestock heads in the area are around 50,000 (Figure 4). Pig and sheep farms are broadly located across most of the municipalities within the study area, although they are especially relevant in the north (Cubel and Used), south (Torralba de los Sisones and Blancas) and southwestern (Odón) boundaries of the study area (Figure 5). On the other hand, cattle farms are exclusively located in Tornos and Cubel. Additionally, there are several areas of traditional extensive grazing for ovine and caprine flocks, which are mostly located in the natural and seminatural areas of the basin.

Figure 4. Surface (ha) of the agricultural lands and livestock population for each municipality in the Gallocanta Basin in 2013

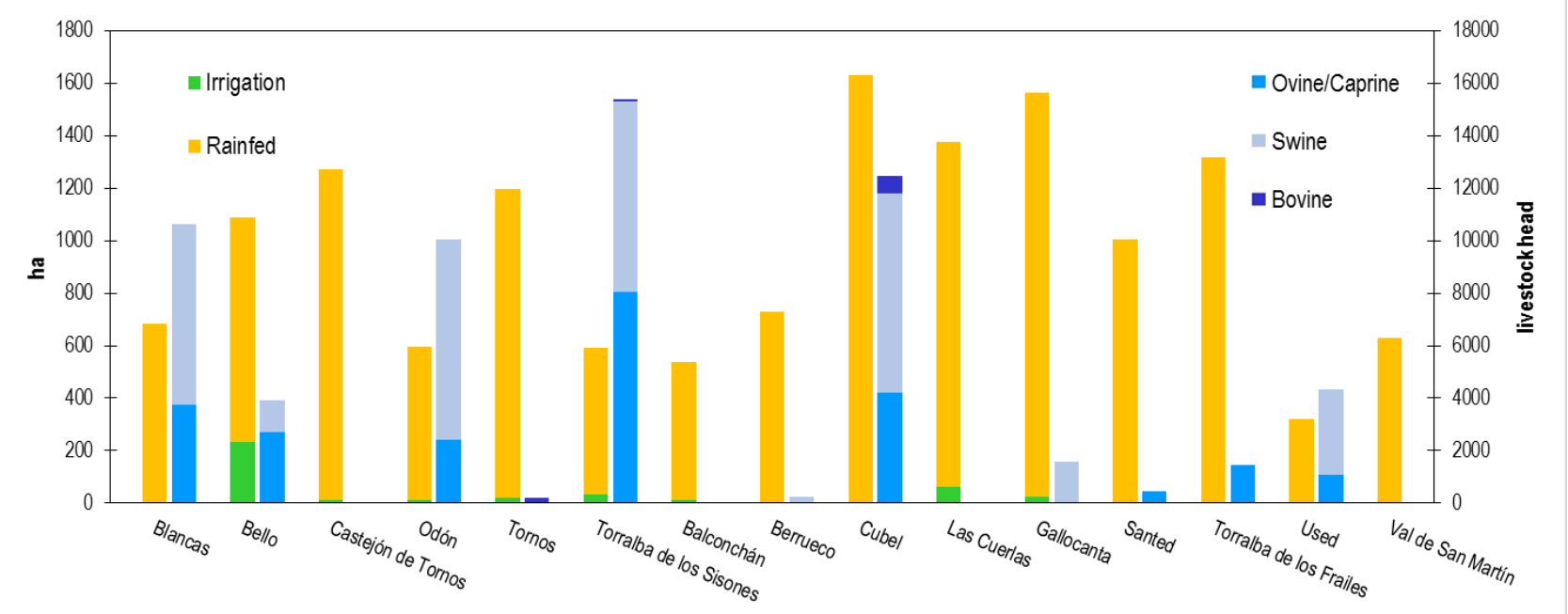

Source: own elaboration 


\section{Methods}

\subsection{Inventory and mapping of the potential hazard sources}

The first step has been the data collection in order to develop accurate variables. Several statistical sources and personal interviews with owners have been used for the inventory. Table 1 shows the variables, the criteria applied for classifying the activities in categories, and the source of information.

Table 1. Inventory of pollution sources

\begin{tabular}{|c|c|c|c|}
\hline Variable & Criteria & Categories & Source \\
\hline Urbanisation & $\begin{array}{l}\text { Urban land uses } \\
\text { according to the } \\
\text { Spanish Cadastre }\end{array}$ & Urban areas & $\begin{array}{l}\text { Spanish Cadastre } \\
(2019)\end{array}$ \\
\hline Isolated houses & $\begin{array}{l}\text { Housing detached } \\
\text { from urban areas }\end{array}$ & $\begin{array}{l}\text { With septic tank } \\
\text { Without septic tank }\end{array}$ & $\begin{array}{l}\text { Spanish Cadastre } \\
\text { (2019) }\end{array}$ \\
\hline Paved surface & $\begin{array}{l}\text { Urban streets and } \\
\text { roads }\end{array}$ & Urban pavement & $\begin{array}{l}\text { Geographical } \\
\text { Institute of Aragon } \\
(2019)\end{array}$ \\
\hline $\begin{array}{l}\text { Waste water } \\
\text { discharges }\end{array}$ & Water treatment & $\begin{array}{l}\text { Treated water } \\
\text { Not treated water }\end{array}$ & $\begin{array}{l}\text { Geographical } \\
\text { Institute of Aragon } \\
(2019)\end{array}$ \\
\hline Dumps & $\begin{array}{l}\text { Interception of the } \\
\text { piezometric level }\end{array}$ & $\begin{array}{l}\text { Reach the piezometric } \\
\text { level } \\
\text { Does not reach the } \\
\text { piezometric level }\end{array}$ & $\begin{array}{l}\text { Spanish Cadastre } \\
\text { (2019) and Ebro } \\
\text { Hydrographic } \\
\text { Confederation } \\
\text { (2018) }\end{array}$ \\
\hline Roads and tracks & Daily Traffic Intensity & $\begin{array}{l}<200 \text { cars/day } \\
200-500 \text { cars/day } \\
500-1000 \text { cars/day }\end{array}$ & $\begin{array}{l}\text { Government of } \\
\text { Aragon (2013) }\end{array}$ \\
\hline Car parking areas & Type of pavement & Pavement & $\begin{array}{l}\text { Spanish Cadastre } \\
(2019)\end{array}$ \\
\hline Cemeteries & Type of burial & $\begin{array}{l}\text { Burial } \\
\text { Niche }\end{array}$ & $\begin{array}{l}\text { Ground truth visit } \\
\text { (2019) }\end{array}$ \\
\hline $\begin{array}{l}\text { Industrial farms } \\
\text { depending on herd } \\
\text { size }\end{array}$ & Number of animals & $\begin{array}{l}<5000 \text { livestock head } \\
5000-10000 \text { livestock } \\
\text { head } \\
>10000 \text { livestock } \\
\text { head }\end{array}$ & $\begin{array}{l}\text { Ebro Hydrographic } \\
\text { Confederation } \\
(2019)\end{array}$ \\
\hline $\begin{array}{l}\text { Industrial farms } \\
\text { depending on } \\
\text { specie }\end{array}$ & Livestock specie & $\begin{array}{l}\text { Swine } \\
\text { Ovine/Caprine } \\
\text { Bovine }\end{array}$ & $\begin{array}{l}\text { Ebro Hydrographic } \\
\text { Confederation } \\
\text { (2019) }\end{array}$ \\
\hline
\end{tabular}


Table 1. Continuation

\begin{tabular}{|l|l|l|l|}
\hline \multicolumn{1}{|c|}{ Variable } & \multicolumn{1}{c|}{ Criteria } & \multicolumn{1}{c|}{ Categories } & \multicolumn{1}{c|}{ Source } \\
\hline $\begin{array}{l}\text { State of conservation } \\
\text { of slurry tanks or } \\
\text { pools }\end{array}$ & Year of construction & $\begin{array}{l}<10 \text { years } \\
10-15 \text { years } \\
>15 \text { years }\end{array}$ & $\begin{array}{l}\text { Aerial } \\
\text { photointerpretation } \\
\text { (PNOA, 2018) }\end{array}$ \\
\hline $\begin{array}{l}\text { Size of the tank or } \\
\text { pool }\end{array}$ & Storage volume & $\begin{array}{l}>10000 \mathrm{hm}^{3} \\
<10000 \mathrm{hm}^{3}\end{array}$ & $\begin{array}{l}\text { Personal interview } \\
\text { with owners }\end{array}$ \\
\hline $\begin{array}{l}\text { Stockpiles of } \\
\text { fertilisers and } \\
\text { pesticides }\end{array}$ & Type of fertiliser & Type of fertiliser & $\begin{array}{l}\text { Personal interview } \\
\text { with owners }\end{array}$ \\
\hline $\begin{array}{l}\text { Agricultural } \\
\text { management }\end{array}$ & $\begin{array}{l}\text { Management intensity } \\
\text { level }\end{array}$ & $\begin{array}{l}\text { Intensive } \\
\text { Non-intensive }\end{array}$ & $\begin{array}{l}\text { Spanish Cadastre } \\
\text { (2019) }\end{array}$ \\
\hline $\begin{array}{l}\text { Agricultural water } \\
\text { management }\end{array}$ & Irrigation type & $\begin{array}{l}\text { Irrigated } \\
\text { Rainfed }\end{array}$ & $\begin{array}{l}\text { Spanish Cadastre } \\
\text { (2019) }\end{array}$ \\
\hline Extensive grazing & Area of extensive & Pasturing area & $\begin{array}{l}\text { Ebro Hydrographic } \\
\text { Confederation } \\
\text { (2019) }\end{array}$ \\
\hline
\end{tabular}

Source: own elaboration

For the inventory and mapping process, aerial photos (PNOA, 2018) have been acquired, collected and utilised for delimiting activities and land uses. Supervised interpretation of the aerial photos was combined with ground truth visits, data from the Government of Aragon, the Ebro Hydrographic Confederation and the Spanish Official Cadastre in order to build an accurate inventory of existing and potential pollutant sources. Detailed information about the location and use of the buildings has been obtained from the Spanish Cadastre. Based on this information, the variables urbanisation, that included the urban areas, and isolated houses, which included houses remote from the villages, were built; and the variable paved surface (paved streets and roads within the urban area) was inferred from the urbanised area. The Spanish Official Cadastre has also been used for distinguishing between different types of crop and water management regimes, e.g. irrigated or non-irrigated areas, with which the variables intensive cultivation lands (rainfed) and intensive cultivation lands (irrigated) were built. Related aspects as soil classification, irrigation type and fertilisation have been considered for classifying the variables according to the indexes' requirements. The data from the Cadastre were essential for the variables road and tracks, dumps and car parking areas. All these activities were categorised by the alphanumeric database of the Spanish Cadastre. Respectively, the Daily Traffic Intensity and type of vehicle, the interception of the piezometric level and the pavement were considered when classifying the variables in each index. Additionally, the information about those variables was complemented by aerial photo interpretation, fieldwork and data collection from the spatial 
database of the Government of Aragon, which allowed us to distinguish specific land uses and activities such as cemeteries (cemeteries), untreated sewage discharges (waste water discharges), waste water pools or tanks (slurry pools or tanks) and production and storing of fertilisers (stockpile of fertilisers).

The geodatabase of the Ebro Hydrographic Confederation was used to obtain spatial information about potential sources of groundwater pollution: the location of water treatment plants and discharges of waste water, which were employed for the variable sewage from treatment plants; the location, the type of livestock and the nitrogen load of farms were considered for the variable industrial farms, and the traditional grazing areas were included in the variable extensive grazing, together with the estimated nitrogen load.

In the cases of the $\mathrm{DCl}$ and the POSH methods, in which additional information about variables is required (e.g. the type of livestock, the type of fertilisation, the area covered by sewage system, the water management, the soil characteristics, etc.), further data and information were collected, analysed and used for the classification of each source in the proper hazard level. This information was also useful for the calculation of the quantity and the likelihood factors of the $\mathrm{HI}$. Once all the information had been collected and mapped, the data have been reviewed, corrected, and updated by 2019, since they had errors related to the type of land uses and the lack of geospatial accuracy.

Following the hazard classification proposed by the hazard methods, all the activities that could potentially be a source of pollution have been categorised in three main groups: urban and infrastructural uses, industrial uses, and agricultural uses. Once the activities had been categorised, ArcGIS 10.5 (ESRI, 2016) has been the GIS software used for the integration, collection, storing, transforming, overlap and displaying of the spatial data. Besides, all the relevant details related to the potential pollution of the activities have also been collected and included as attributes in a data base, e.g. size, area, year of construction, population, etc.

\subsection{Hazard indexes application}

Three independent hazard indexes have been selected for hazard mapping: the Hazard Index $(\mathrm{HI})$, proposed by De Keteleare et al., (2004), the DCI index (Civita and De Maio, 1997), and the POSH index (Foster et al., 2002). The methods have been applied in the study area and afterwards a comparative analysis of the results has been carried out. The aim has been to assess the potentialities and weaknesses of each method, as well as their suitability for hazard mapping. The mapping process has been developed as described below: 
a) Hazard Index (De Ketelaere et al., 2004)

Based on the step-by-step procedure proposed in the framework of the COST Action 620 (De Ketelaere et al., 2004), the hazard map was reached following the described instructions:

- Step 1: Definition and inventory of hazards

The objective is to cover all the hazards that may be significant to groundwater in a practical and economically feasible manner. A three-level classification is proposed to categorise hazards for groundwater protection purposes. Level I distinguishes hazards in three main categories according to the land use, i.e. infrastructural, industrial and agricultural activities (Table 2). Level II is based on the main source of possible contamination (solid or liquid contaminants), and is referred to the types of industrial or agricultural activities, including their specific range of contaminants. Finally, Level III describes 96 specific activities and specific land uses related to the Level II of subdivision.

Table 2. Classification of hazards observed in the study area, according to the $\mathrm{HI}$

\begin{tabular}{|l|l|}
\hline \multicolumn{1}{|c|}{$\begin{array}{c}\text { LEVEL I CATEGORIES OF } \\
\text { HAZARDS }\end{array}$} & \multicolumn{1}{|c|}{ LEVEL II CATEGORIES OF HAZARDS } \\
\hline Infrastructural development & Waste water \\
& Municipal waste \\
& Fuels \\
& Transport and traffic \\
& Recreational facilities \\
& Diverse hazards \\
\hline Industrial activities & Mining (in operation and abandoned) \\
& Excavation sites \\
& Oil and gas exploration \\
& Industrial plants \\
& Power plants \\
& Industrial storage \\
& Diverting and treatment of waste water \\
\hline Livestock and agriculture & Livestock \\
& Agriculture \\
\hline
\end{tabular}

Source: De Ketelaere et al. (2004)

- Step 2: Hazard Data Requirements

The aim of assessing the potential harmfulness of each hazard requires information on the nature of the activity, the type of the substance, the amount of substance that can be released, or the status of the installation. Information about the nature of the activity have been obtained from the Spanish Cadastre, data related to the type of the substance and the status of the installation were 
collected from the Government of Aragon and the amount of substance that can be release has been estimated by using aerial photo to measure the size of the sources of pollution (plots, slurry pools, dumps, etc.). That information was complemented with fieldwork and personal communication with farmers and local population.

- Step 3: Rating and Weighting of Hazards

The $\mathrm{HI}$ considers three factors for the hazard assessment process: the toxicity of the pollutant $(H)$, the quantity of pollutant that can be released $\left(Q_{n}\right)$, and the likelihood of a hazardous event $\left(R_{f}\right)$. The proposed weighting values of the $H$ factor vary between 10 and 100 . The criteria for weighting hazards are related to the toxicity, solubility and mobility of relevant substances associated with each type of hazard. Thus, the determination of weighting coefficient judges the potential degree of harmfulness of those hazards. Beyond the degree of harmfulness, the quantity of a harmful substance that can be release is also a relevant factor when ranking hazards. In order to improve the rating process maintaining a fair balance with the $H$ values, a ranking $\left(Q_{n}\right)$ factor between 0.8 (low) and 1.2 (high) is multiplied by H. Finally, the third relevant factor in the rating process is the likelihood $\left(R_{f}\right)$ of a hazardous event based on the infrastructural level of maintenance, the security measures adopted, or the surrounding conditions. This factor ranges between 1 (when no reduction of the probability takes place) and 0 (when there is no risk of groundwater contamination).

The method leaves the specialists to ascribe $Q_{n}$ and $R_{f}$ values based on the existing factors that influence the quantity of harmful substance and the likelihood of a hazardous event. In our case, those factors were adapted to the study area casuistry and to the available data. The factors were directly or indirectly related to the potential amount of pollutant that can be released (Table 3), as well as to the likelihood of discharge (Table 4). In order to ease the hazard mapping process, $Q_{n}$ and $R_{f}$ factors were modified when published and trustworthy information was available. Finally, the criteria for ranking $Q_{n}$ and $R_{f}$ were established according to the range of values of each hazard in the study area. Both Table 3 and Table 4 show the hazard, the criteria used for ranking the $Q_{n}$ and the $R_{f}$ factors, the source of information and the range of values. 
Table 3. Criteria for the modification of the $Q_{n}$ factor in the study area

\begin{tabular}{|l|l|l|l|}
\hline \multicolumn{1}{|c|}{ HAZARD } & \multicolumn{1}{|c|}{ CRITERIA } & \multicolumn{1}{c|}{ SOURCE (year) } & RANGE \\
\hline Urbanisation & Built-up area & Spanish Cadastre (2019) & $0.8-1.2$ \\
\hline $\begin{array}{l}\text { Waste water discharges } \\
\text { into surface courses }\end{array}$ & $\begin{array}{l}\text { Number of inhabitants } \\
\text { dumping waste water }\end{array}$ & $\begin{array}{l}\text { Spanish Statistical Office } \\
\text { (INE on its Spanish } \\
\text { Acronym) (2018) }\end{array}$ & $0.8-1.2$ \\
\hline Road & Daily Traffic Intensity & $\begin{array}{l}\text { Government of Aragon } \\
\text { (2013) }\end{array}$ & $0.8-1.2$ \\
\hline Car parking area & Size of the parking & Spanish Cadastre (2019) & $1-1.2$ \\
\hline Agriculture & $\begin{array}{l}\text { Type of crop according to its } \\
\text { fertilisation needs }\end{array}$ & Spanish Cadastre (2019) & $0.8-1.2$ \\
\hline Factory farm & Size of the facilities & Spanish Cadastre (2019) & $0.8-1.2$ \\
\hline Slurry storage tanks & Volume storage & Spanish Cadastre (2019) & $0.8-1.2$ \\
\hline
\end{tabular}

Source: own elaboration

Table 4. Criteria for the modification of the $R_{f}$ factor in the study area

\begin{tabular}{|l|l|l|l|}
\hline \multicolumn{1}{|c|}{ HAZARD } & \multicolumn{1}{|c|}{ CRITERIA } & \multicolumn{1}{c|}{ SOURCE } & RANGE \\
\hline Cemetery & Type of burial & Ground truth visit & 0.8 \\
\hline Car parking area & Type of pavement & Spanish Cadastre (2019) & $0.95-1$ \\
\hline Agriculture & $\begin{array}{l}\text { Water management (rainfed } \\
\text { or irrigation) }\end{array}$ & Spanish Cadastre (2019) & $0.9-1$ \\
\hline Slurry storage tank & Year of construction & Aerial photo & 0.9 \\
\hline Stockpile of fertilisers & Protection measures & Personal interview & 0.9 \\
\hline
\end{tabular}

Source: own elaboration

- Step 4: Calculation of the Hazard Index (HI) and mapping

The $\mathrm{HI}$ describes the degree of harmfulness of each hazard. The following formula is used for its calculation:

$$
H I=H \times Q_{n} \times R_{f}
$$

Where $H$ is the hazard index, $H$ is he weighting value of each hazard, $Q_{n}$ is the ranking factor, and $R_{f}$ is the reduction factor.

The range of $\mathrm{HI}$ is $\mathrm{O}-120$ scores. For an appropriate interpretation, when mapping the index, a subdivision of less than five or six classes and a proper scale of the data and the map output are suggested. In addition, when more than one hazard overlaps, it is also recommended to show the one that has the higher score. 
b) Danger Contamination Index (Civita \& De Maio, 1997)

This method was proposed by Civita and De Maio (1997), aiming to territorialise the risk from the contemporary presence of several contamination sources. This method is based on intrinsic hazard criteria, i.e. the specific characteristics of the sources of pollution. A Danger of Contamination Index (DCl) value, ranging from 1 to 9 , is individually attributed to industrial, agricultural and livestock activities, and other punctual contamination sources. Table 5 summarises the $\mathrm{DCl}$ classification.

Table 5. Classification of the hazards observed in the study area according to the $\mathrm{DCl}$

\begin{tabular}{|c|c|c|c|}
\hline $\mathrm{DCl}$ & CATTLE BREEDING & $\begin{array}{l}\text { OTHER PUNCTUAL } \\
\text { SOURCES }\end{array}$ & AGRICULTURE \\
\hline 8 & & $\begin{array}{l}\text { Storage tanks of toxic } \\
\text { and/or hazardous } \\
\text { waste }\end{array}$ & \\
\hline 7 & & USW unlined disposals & \\
\hline 6 & & & $\begin{array}{l}\text { Cultivation with high chemical } \\
\text { support }\end{array}$ \\
\hline 5 & $\begin{array}{l}\text { Intensive swine, poultry, rabbit, } \\
\text { breeding with more than } 500 \\
\text { quintals of live breeding weight }\end{array}$ & & $\begin{array}{l}\text { Cultivation with limited chemical } \\
\text { support and with spreading of } \\
\text { swine and rabbit manure }\end{array}$ \\
\hline 4 & $\begin{array}{l}\text { Intensive swine, breeding with } \\
\text { less than } 500 \text { quintals of live } \\
\text { breeding weight } \\
\text { Intensive sheep/goat breeding } \\
\text { and horse breeding }\end{array}$ & & \\
\hline 3 & $\begin{array}{l}\text { Intensive cattle with more than } \\
50 \text { units }\end{array}$ & & $\begin{array}{l}\text { Cultivation with limited chemical } \\
\text { support and Spreading of cattle } \\
\text { manure }\end{array}$ \\
\hline 2 & Generic farm or wild livestock & & $\begin{array}{l}\text { Cultivation (fruit, vineyard or } \\
\text { seed) with limited chemical } \\
\text { support }\end{array}$ \\
\hline 1 & & & Grazing \\
\hline
\end{tabular}

Source: Civita \& De Maio (1997)

Furthermore, in order to take into account the presence of structural and non-structural protection actions, the authors recommended a reclassification at a lower hazard level, reducing the $\mathrm{DCl}$ value when necessary, following the operator criteria. At the same time, for some industries, the operator should also choose the $\mathrm{DCl}$ value based on the type of work, the water consumption rate, the existence of effluents storage, or the discharge of substances of a high potential impact on the quantity and quality of the groundwater. 
c) Pollutant Origin Surcharge Hydraulically (Foster et al., 2002)

The Pollutant Origin Surcharge Hydraulically (POSH) method was created by Foster \& Hirata in 1988 and modified by Foster et al. (2002), and it can be used to classify the pollutant emissions into groundwater. The method focuses on the source of the pollutant and on its hydraulic surcharge by using the location and the size of the potential pollutant activity, the type of activity and the water consumption.

The method distinguishes between punctual contamination sources and multi-punctual and diffuse contamination sources (Table 6 and Table 7). The multi-punctual and diffuse classification categorises urban wastewater discharges and agricultural activities, whereas the punctual classification includes urban solid waste, industry, refuse tanks, urban activities and mining and oil industries. This method opts for a qualitative ranking instead of a score grading rank; thus, it proposes a simple classification of the activities according to its potential of contamination: high, moderate and low. In case more than one activity overlaps, it is suggested to show the one with the highest level.

Table 6. Classification of the point pollution sources observed in the study area, according to the POSH method

\begin{tabular}{|c|l|l|}
\hline $\begin{array}{c}\text { Subsurface contaminants } \\
\text { Load Potential }\end{array}$ & \multicolumn{1}{|c|}{ POLLUTION SOURCE } \\
\cline { 2 - 3 } Elevated & $\begin{array}{l}\text { In sanitation } \\
\text { Population density } \\
>100 \text { inhab/ha }\end{array}$ & $\begin{array}{l}\text { Antensive cash crops and most } \\
\text { monocultures on well-drained soils in } \\
\text { humid climates or with low-efficiency } \\
\text { irrigation, intensive grazing on heavily } \\
\text { fertilised meadows }\end{array}$ \\
\hline Moderate & Intermediate between above and below \\
\hline Reduced & $\begin{array}{l}\text { Population density }<50 \\
\text { inhab/ha }\end{array}$ & $\begin{array}{l}\text { Traditional crop rotations, extensive } \\
\text { pasture land, high-efficiency irrigated } \\
\text { cropping in arid areas }\end{array}$ \\
\hline
\end{tabular}

Source: Foster et al. (2002) 
Table 7. Classification of the diffuse pollution sources observed in the study area, according to the $\mathrm{POSH}$ method

\begin{tabular}{|c|l|l|l|}
\hline \multirow{2}{*}{$\begin{array}{c}\text { Subsurface } \\
\text { contaminants } \\
\text { Load Potential }\end{array}$} & \multicolumn{1}{|c|}{ Solid waste disposal } & Wastewater lagoons & \multicolumn{1}{|c|}{$\begin{array}{c}\text { Miscellaneous } \\
\text { urban }\end{array}$} \\
\cline { 2 - 4 } Elevated & & $\begin{array}{l}\text { Any effluent if area } \\
>5 \text { ha }\end{array}$ & \\
\hline \multirow{2}{*}{ Moderate } & $\begin{array}{l}\text { Rainfall }>500 \mathrm{~mm} / \mathrm{y} \text { with } \\
\text { residential/ industrial type } \\
1 / \text { agro-industrial wastes, } \\
\text { all other cases }\end{array}$ & $\begin{array}{l}\text { Residential sewage if } \\
\text { area }>5 \text { ha, other cases }\end{array}$ & \\
\hline Reduced & $\begin{array}{l}\text { Rainfall <500mm/y with } \\
\text { residential/agro-industrial } \\
\text { wastes }\end{array}$ & $\begin{array}{l}\text { Residential, mixed } \\
\text { urban, agro-industrial }\end{array}$ & Cemeteries \\
\hline
\end{tabular}

Source: Foster et al. (2002)

\subsection{Comparative assess of the hazard indexes}

The use of different ranks when scoring land uses and the heterogeneity of the quantifying process make harder to reach conclusions about the efficiency of each method. Aiming to ease comparison, a two-steps standardisation process of the scores given by the $\mathrm{HI}$, the $\mathrm{DCl}$, and the POSH indexes to potentially hazardous activities was carried out. First, the scores were reclassified to a 1 to 10 quantitative increasing scale, from very low to very high hazard levels. On the second step, the scores were then gathered in a five-interval regular and qualitative classification, which was used for mapping. The resulting classification includes five classes: very low, low, moderate, high and very high hazard levels, which is reproducible and can be easily followed by a non-specialist public. Table 8 shows the equivalence of the original scores and the quantity and qualitative standardised classification. 
Table 8. Summary of the intervals of the $\mathrm{HI}$, the $\mathrm{DCl}$ and the POSH approaches, and the standardised classification used for comparison

\begin{tabular}{|c|c|c|c|c|}
\hline $\begin{array}{l}\text { STANDARDISED } \\
\text { SCORES }\end{array}$ & $\begin{array}{l}\text { STANDARDISED } \\
\text { INTERVALS }\end{array}$ & HI & DCI & POSH \\
\hline 1 & \multirow{2}{*}{ Very low } & $1-12$ & 1 & \multirow{3}{*}{ Low } \\
\hline 2 & & $12-24$ & \multirow{2}{*}{2} & \\
\hline 3 & \multirow{2}{*}{ Low } & $24-36$ & & \\
\hline 4 & & $36-48$ & 3 & \multirow{5}{*}{ Moderate } \\
\hline 5 & \multirow{3}{*}{ Moderate } & 1060 & 4 & \\
\hline & & & \multirow[t]{2}{*}{5} & \\
\hline 6 & & $60-72$ & & \\
\hline 7 & \multirow{2}{*}{ High } & $72-84$ & 6 & \\
\hline 8 & & $84-96$ & 7 & \multirow{3}{*}{ High } \\
\hline 9 & \multirow{2}{*}{ Very high } & $96-108$ & 8 & \\
\hline 10 & & $108-120$ & 9 & \\
\hline
\end{tabular}

Source: own elaboration

\section{Results}

\subsection{Hazard inventory}

A series of activities were inventoried as potential pollution sources in the study area and they were gathered in urban and agricultural sources. The $\mathrm{HI}$, the $\mathrm{DCl}$ and the POSH indexes list different contamination sources according to their methodological approach. Table 9 shows the hazards listed in each index and Figure 5 displays the spatial location of those sources of pollution. 
Figure 5. Inventory of the potential pollution sources. Unclassified hazard map

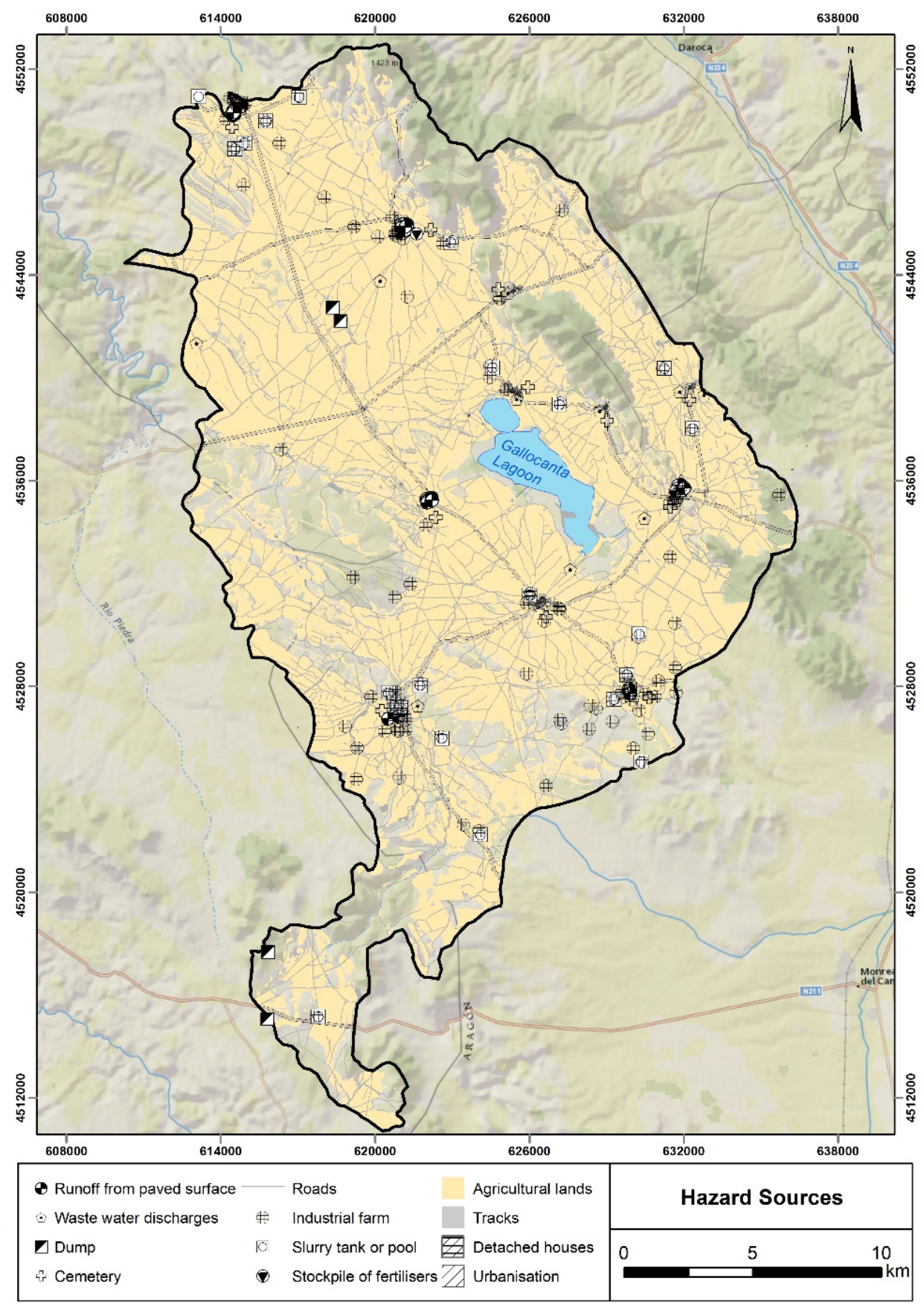

Source: own elaboration 
Table 9. Inventory of the potential pollution sources considered by each method in the study area

\begin{tabular}{|c|c|c|c|c|}
\hline CLASS & HAZARD & $\mathrm{HI}$ & $\mathrm{DCl}$ & $\mathrm{POSH}$ \\
\hline \multirow{9}{*}{ Urban hazards } & Urbanisation & . & & . \\
\hline & Isolated houses & . & & \\
\hline & Paved surfaces & . & & \\
\hline & Waste water discharges & . & & . \\
\hline & Sewage from treatment plants & . & & . \\
\hline & Dumps & . & . & . \\
\hline & Roads and tracks & . & & \\
\hline & Car parking areas & . & & \\
\hline & Cemeteries & . & & . \\
\hline \multirow{6}{*}{$\begin{array}{l}\text { Agriculture and } \\
\text { livestock }\end{array}$} & Industrial farms & . & . & . \\
\hline & Slurry pools & . & . & . \\
\hline & Stockpiles of fertilisers and pesticides & . & & \\
\hline & Intensive cultivation lands (rainfed) & . & . & . \\
\hline & Intensive cultivation lands (irrigated) & . & . & . \\
\hline & Extensive grazing & & . & . \\
\hline
\end{tabular}

Source: own elaboration

\subsection{Hazard mapping}

a) HI Method

The hazard map (Figure 6) allowed to conclude that the main class of hazard index is low type ( $66.5 \%$ of the study area), and only a few punctual pressures of very low $(<1 \%)$ and moderate $(<1 \%)$ hazard levels were found. The scores of the $\mathrm{HI}$ in the study area ranged between 18 and 54 (Figure 10). The predominant low level was given to waste water infrastructures, e.g. urbanisation with sewer systems, drains for runoff from paved surfaces, and waste water treatment and discharge plants; transport infrastructures, e.g. roads and tracks; agricultural land uses, e.g. rainfed and irrigated areas; and livestock facilities, e.g. farms and modern slurry storage tanks and pools. On the other hand, very low hazard level included certain rainfed crops with low fertilising needs, small farms, animal barns, and cemeteries, whereas isolated houses without sewer systems, old slurry storage pools and waste water discharge pipelines without treatment, were classified as moderate hazard level activities. Neither high nor very high hazard level activities were found in the study area. The most hazardous activities considered by the $\mathrm{HI}$ were isolated houses without sewer systems and waste water discharge into surface water courses $(H=45)$, which were included within the infrastructural group, and pools of slurry storage $(H=45)$, included within the agriculture and livestock group. 
Figure 6. Groundwater pollution hazard map of the Gallocanta Catchment (HI Method)

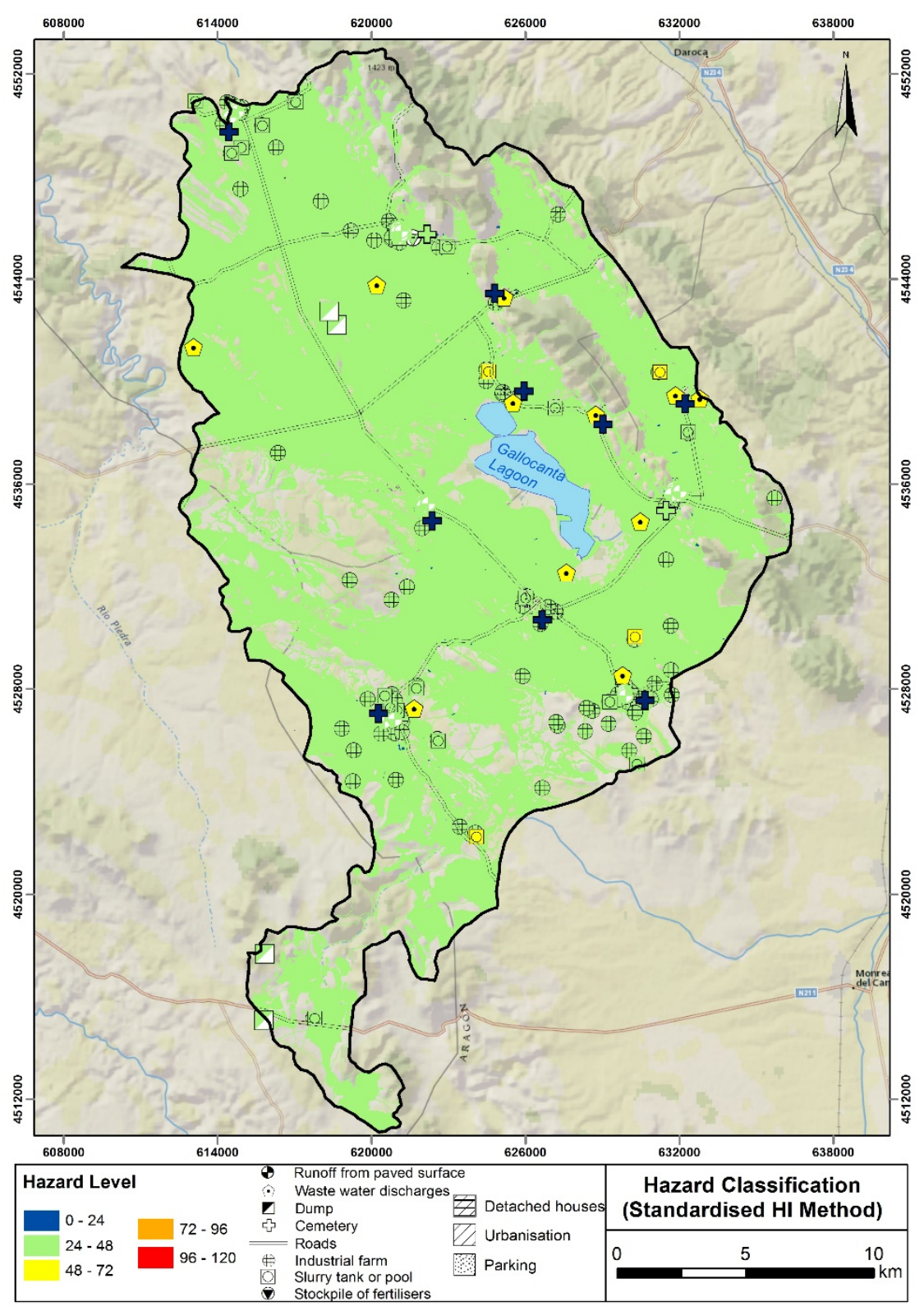

Source: own elaboration

\section{b) DCl Method}

The map shows the hazard classification based on the DCl method (Figure 7). In the study area, the $\mathrm{DCl}$ ranges between 1 and 8 . Thus, no extreme values of 9 were given to any land use in the basin (Figure 10). According to the hazard ranking, most of the area may be classified in the moderate hazard level ( $63.5 \%$ of the study area scores between 4 and 6 ), whereas $<1 \%$ of the study area is ranked in the low $(\mathrm{DCl}=2-3)$ or high $(\mathrm{DCl}=8)$ hazard level. Intensive livestock farming, irrigated areas and rainfed crops, were classified as moderate, storage of hazardous wastes from farming was designated as high, and generic farms and crops with limited chemical support (fruit and vineyards) were considered as low hazardous activities. Extensive grazing areas 
were also considered as low hazardous activities $(\mathrm{DCl}=1)$. Therefore, the most harmful activity is the storage of toxic or hazardous wastes in tanks or pools $(\mathrm{DCl}=8)$.

Figure 7. Groundwater pollution hazard map of the Gallocanta Catchment (DCI method)

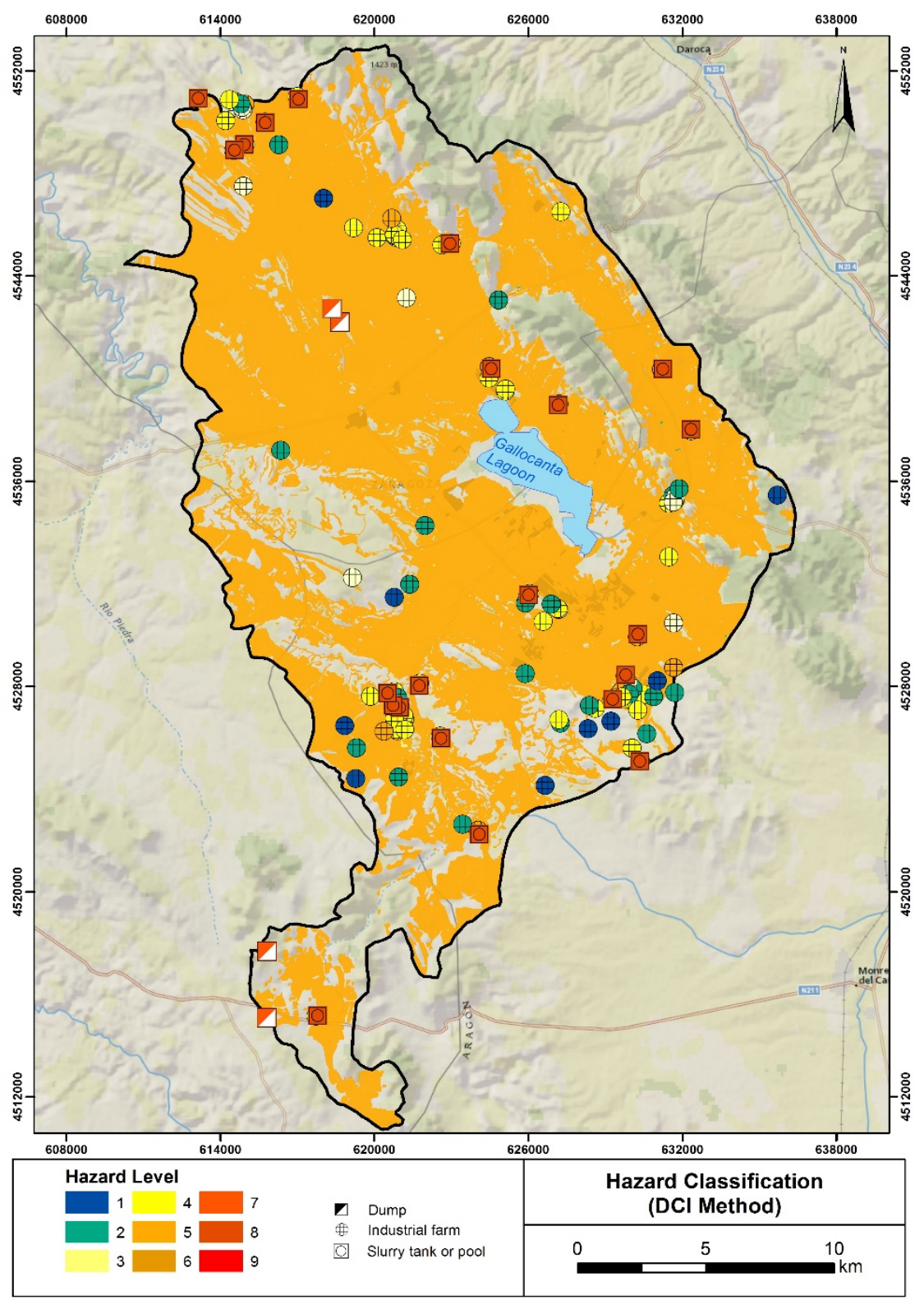

Source: own elaboration

\section{c) POSH Method}

In this case, the low range of the hazard classification allows to classify activities within the three levels of hazard (Figure 10). The majority of the study area has been designated in the low hazard level (62.9\%) due to rainfed agricultural lands, extensive pasturelands, urban areas with sewer systems and low population density, and small graveyards. The moderate $(<1 \%)$ and the high level $(<1 \%)$ have been only found in isolated plots. The latter was basically related to 
irrigation areas, whereas the moderate designation belongs to factory farms, waste water treatment and discharge plants, and slurry tanks (Figure 8).

Figure 8. Groundwater pollution hazard map of the Gallocanta Catchment (POSH Method)

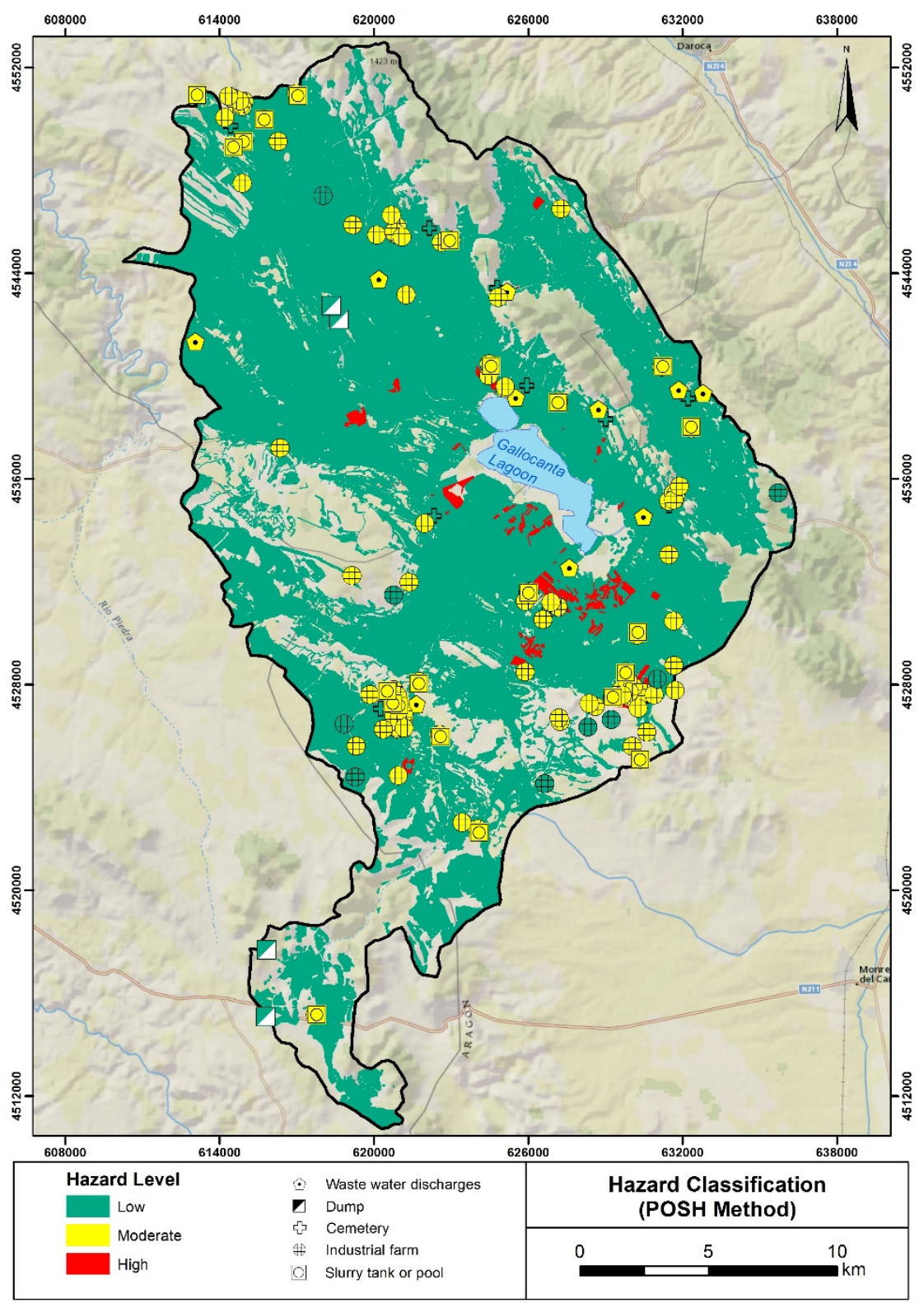

Source: own elaboration

\subsection{Hazard mapping standardisation}

In the case of the standardised $\mathrm{HI}$ method, no changes were found in the interval's classification due to the similar gathering process used by both indexes. Nevertheless, more notorious variation could be observed when reclassifying the $\mathrm{DCl}$ and the $\mathrm{POSH}$ classes. 
Table 10. Surface extension of hazards according to the standardised hazard index

\begin{tabular}{|l|l|l|l|l|l|}
\hline \multicolumn{1}{|c|}{ Index } & Very Low (\%) & \multicolumn{1}{c|}{ Low (\%) } & \multicolumn{1}{c|}{ Moderate (\%) } & High (\%) & $\begin{array}{c}\text { Very High } \\
(\%)\end{array}$ \\
\hline $\mathrm{HI}$ & $<0.05$ & 66.5 & $<0.05$ & & \\
\hline $\mathrm{DCl}$ & & $<0.05$ & 63.5 & $<0.05$ & \\
\hline $\mathrm{POSH}$ & & 62.9 & $<0.05$ & 0.84 & \\
\hline Stand. $\mathrm{HI}$ & $<0.05$ & 66.5 & $<0.05$ & & \\
\hline Stand. DCl & & 0.05 & 62.7 & 0.84 & $<0.05$ \\
\hline Stand. POSH & & 0.15 & 62.7 & 0.03 & 0.84 \\
\hline
\end{tabular}

Source: own elaboration

Figure 9 shows the maps obtained after the standardisation procedure. In relation to the standardised DCI (Figure 9), less than $1 \%$ of the study area was considered in the low $(0.05 \%)$, high $(0.84 \%)$ or very high $(<0.01 \%)$ classes, whereas $62.7 \%$ of the territory was situated in areas with a moderate hazard level. In the case of the standardised POSH index, the sum of the extension of the low, high and very high classes $(0.15 \%, 0.03 \%$ and $0.84 \%$, respectively) represents the $1 \%$ of the study area. Meanwhile, the rest of the basin (62.7\%) was included in the moderate hazard level. As shown in Table 10, even after the standardisation procedure, still no areas of high or very high hazard levels were found in the $\mathrm{Hl}$, where the low interval is the uppermost. On the contrary, the Standardised POSH index and the DCl did not classify any activity in the very low hazard level. Overall, the DCI and the POSH indexes ranked activities in the same intervals, but the classification of those activities varies from one to another. Whereas the $\mathrm{DCl}$ mostly ranked activities in the moderate level, the same activities are classified in the low or high levels in the POSH index. After the standardisation, the moderate level become into the dominant interval both in the $\mathrm{DCl}$ and the POSH methods, although slight differences still exist, especially in the high and very high intervals. 
Figure 9. Standardised hazard maps of the Gallocanta Catchment
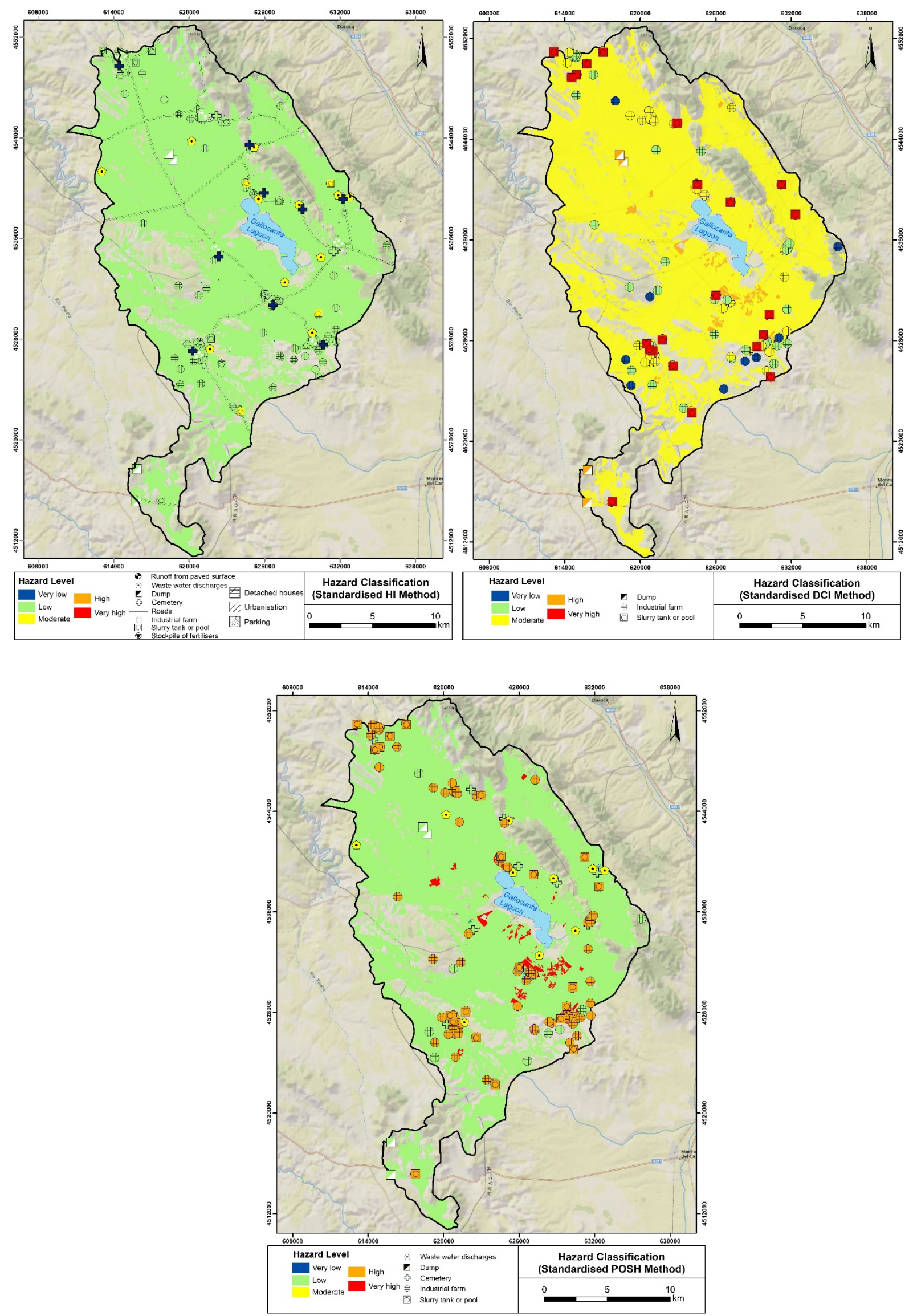

Source: own elaboration 


\section{Discussion}

The comparison of the results highlights a series of differences in relation to the hazard classification in the study area, which are based on the different methodological conception of each index. Those variable methodological approaches are evidenced in three aspects described below: the heterogeneity of the hazard rating process, the differences in the inventory of hazards, and the influence of factors such as likelihood or quantity.

\subsection{Differences related to the rating procedure}

It has been already mentioned that the Level I of the $\mathrm{HI}$ index distinguishes between infrastructural facilities, industrial activities and agricultural and livestock land uses. This is a standard classification that can be easily used for any kind of regional analysis. It is similar to the one selected by the $\mathrm{DCl}$ and by the POSH. The first considers industry, cattle breeding, agriculture and other punctual sources related to urbanisation and infrastructures, whereas POSH separates punctual and non-punctual sources but also distinguishes among industry, oil and mine activities, agricultural practises, urban discharges, and other activities such as urban solid waste, waste water pools or sewer systems. Setting a weighting system based on the harmfulness of the potential pollutant allows a comparison between the different types of hazards (De Ketelaere et al., 2004). However, a quantitative comparison of the weights has revealed significant differences both between activities in a certain index and between the same activities in each index.

Due to the toxicity of the pollutants and to the long residence time in the groundwater system, industrial activities have been generally considered highly harmful for groundwater (Gallagher et al., 2008; Pal, 2017, Santucci et al., 2018). However, due to the different types of industry, not all of them have been classified with the same hazard level. The variation in industries typologies has been reflected in the scores of the $\mathrm{HI}$, the $\mathrm{DCl}$ and the POSH indexes, since the industry group have had the widest range of scores. Overall, the most hazardous activities belong to the industry group (e.g. nuclear waste site, petroleum refining and chemical, gas, and oil industries). These activities have been considered significantly more harmful than the most hazardous activities from the agriculture and livestock group (waste water irrigation, $\mathrm{H}=60$; cultivation with high chemical support, $\mathrm{DCl}=6$; and intensive cultivation zones, $\mathrm{POSH}=$ High) but similar to the infrastructural group (waste water injection well, $\mathrm{H}=85$; toxic or hazardous unlined waste disposal, $\mathrm{DCl}=9$; and abandoned urban areas, $\mathrm{POSH}=$ High). 
The variation in the classification of the slurry storage tanks in each index could be useful for analysing how the differences in the methodological approach can modify the weight they give to each activity and thus, the hazard map. Both the $\mathrm{HI}$, the $\mathrm{DCl}$ and the POSH methods listed this activity, but whereas the first classifies it within the moderate hazard level, the DCl included it as a highly hazardous activity, and the POSH method listed it in the low hazard level. The consequence of this heterogeneity on the hazard classification may be the design of confusing maps that are not representative. The lack of specific criteria when assessing groundwater hazards is also evident if an analysis of the land uses' classifications is done. In the HI, during the weighting step, every type of crop is treated in the same way, without taking into account plant needs nor irrigation regime. Cultivation areas are therefore ranked between the very low hazard level and the low hazard level. The consequences are homogeneous maps that are not representative of the real hazard of those areas. On a different perspective, the $\mathrm{DCl}$ and the $\mathrm{POSH}$ index methodologies try to make differences between agricultural areas based on the crops needs, the presence of irrigated or rainfed areas and the use of fertilisers. The result is a better resolution on the potential hazard of cultivation areas.

Apart from the methodological approach of each index for the weighting procedure, the differences between the scores range, and the use of quantitative and qualitative classification, made hard the comparison of hazard maps. In order to allow the comparison of the hazard ranks, a standardisation of the scores was performed. Figure 10 shows the ranges of the scores for each index and for the related standardised index in the study area. As shown, the standardisation process slightly changes the hazard ranking used by each method. The HI scores remain in the same intervals after the standardisation procedure, since the original classification in five intervals is similar to the categorisation used by the standardised index. In the case of the $\mathrm{DCl}$, the range of scores in the study area was from 1 to 8 , whereas the modified index ranges between very low and very high levels. On the other hand, the POSH index completely covered the spectrum of classification. Nevertheless, the standardised POSH index ranged from low to very high level. Compared with the $\mathrm{DCl}$ and the POSH index, the $\mathrm{HI}$ showed a tendency to underrate hazard in spite of the standardisation. 
Figure 10. Score and interval ranges for the original and the standardised methods

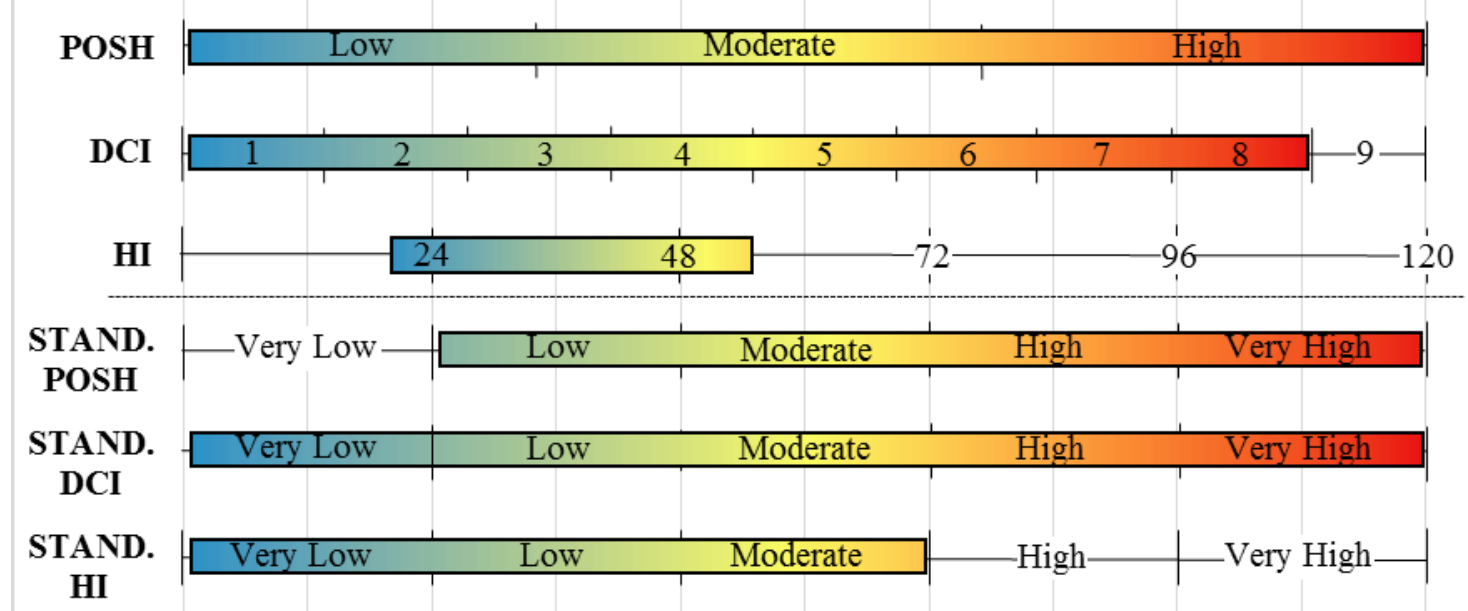

Source: own elaboration

Furthermore, the differences in the hazard level during the rating process and its proportional characteristics may be masked by the unappropriated designation of intervals when classifying and mapping the hazards. This issue was especially evident for the $\mathrm{HI}$, where the wide range of scores leaded to categorise several intervals. The authors suggested a subdivision of less than five or six intervals (De Ketelaere et al., 2004), so, following the indications, a five-interval classification was applied for the $\mathrm{HI}$ in the study area. However, due to the territorial context, the prevalence of low level hazardous activities, and the reduced area of moderate and very low hazardous activities, the resulting map barely differentiates between intervals. A similar issue occurs when mapping the $\mathrm{DCl}$, which distinguishes nine categories of hazard. In this case, the POSH index only distinguishes three levels of hazard. This simple classification may ease the map creation process and the reader understanding, although details have been lost due to the generalisation approach.

\subsection{Differences related to the inventory of hazards}

In regard to the lack of heterogeneity of the hazard maps, the influence of the number of activities listed in each index should also be taken into account. If a short list of land uses tends to the generalisation of hazards, a too detailed list of activities, similar to the one proposed by the $\mathrm{HI}$, is undoubtedly useful. However, very diverse study areas were needed since, in territories with a low variety of land uses, the index was prone to be little discriminant. In those cases, land uses usually had similar pollution potential, thus, they were gathered in the same interval. In this type of areas, approaches with narrower score ranges may represent results in a more heterogeneous way. This is the case of the Gallocanta Basin, where the predominance of 
agricultural and livestock activities is reflected in a homogeneous hazard classification for the $\mathrm{HI}$, whereas the POSH index shows activities within the high, the moderate and the low hazard levels. The values of the activities categorised by the $\mathrm{HI}$ range between 18 and 54, so they all are classified in the very low, low, or moderate intervals, while the $\mathrm{DCl}$ and the $\mathrm{POSH}$ indexes range between 1 and 8 and from low to high levels, respectively. Therefore, extreme values are not represented in the study area.

The different approaches during the inventory of hazard steps were related to the list of hazards classified by each index. Although the indexes followed a similar classification, they did not distinguish the same sources of pollution and the degree of detail they reached was variable. As a consequence, in methods that did not list detailed sources (e.g. the DCl and the POSH), several sources may be uncatalogued and thus, hazard level would be inaccurate. For example, in the Gallocanta Basin, conventional roads, rural tracks, isolated houses without sewer systems and cultivation lands could be considered as important sources of pollution. Nevertheless, roads, tracks and isolated houses are not included in the $\mathrm{DCl}$ nor in the $\mathrm{POSH}$ index classification, whereas agricultural lands are not extensively classified in the HI. As aforementioned, the agricultural plots, are the main land use in the Gallocanta basin. Traditionally, agriculture has been widely recognised as one of the most hazardous activities for groundwater quality (Sutton et al., 2011; Wick et al., 2012; Zhang et al., 2019), due to the leaching of fertilisers and pesticides used for increasing production. Consequently, in agricultural areas, the most frequent pollutants are nitrates and other contaminants related to fertilisation, which could be considered less harmful than contaminants from industrial or urban sources and are easier to mitigate by natural dissolution (Vías, 2005). This author observed that the $\mathrm{HI}$ index is intrinsically weak when rating the hazard level of some sources of pollution. In this regard, the low hazard level associated to most of the urban and agricultural sources in the study area were based on the conceptual approaches of the indexes and on the idea of the lower persistence of the pollutants, especially compared to other types of substances like heavy metals or industrial sewage (Burri et al., 2019). However, the fact is that most of the groundwater bodies that have been declared as affected by nitrate contamination in the EU last years or decades to recover a good quality status (EC, 2018).

Whereas in industrial and urban areas the pollution is mostly punctual or lineal, and is basically based on an accident or a hazardous event, diffuse pollution from agriculture provides a slow but constant flux of pollutants to groundwater, which is hard to prevent and control. The most extended way to protect groundwater is related to the implementation of action programmes that establish legal threshold of fertilisation, control measures, and fertilisation rates (Worrall et al., 
2009). The establishment of a specific law for nitrate pollution from agricultural sources in the EU (ND 91/671/EEC) and the implementation of several NVZs across the continent serve as a reference of the magnitude of this issue in Europe.

In spite of this, the $\mathrm{HI}$ and the DCl classify agriculture below moderate hazard level, and only the $\mathrm{POSH}$ method put intensive agriculture areas with low irrigation efficiency on the same level that pollutants from heavy industries. This fact could be contradictory with the current groundwater situation in the Gallocanta Basin, since mean nitrate concentration in the aquifers is above the legal threshold of $50 \mathrm{mg} \mathrm{L}^{-1}$, and some sites reach concentrations of $120 \mathrm{mg} \mathrm{L}^{-1}(\mathrm{CHE}, 2016)$. The idea of the agriculture undervaluation as a source of pollution is supported by two evidences. On one hand, the GGB is partially declared as a Nitrate Vulnerable Zone, therefore, the use of fertilisers is legally established. On the other hand, intrinsic vulnerability of the area to groundwater pollution is not very high (CHE, 2019). Both facts seem to highlight that the risk of groundwater pollution has been underrated due to inaccurate rating of diffuse pollution sources, mainly agricultural activities.

\subsection{Differences related to the treatment of quantity and probability}

The hazard indexes base the hazard classification on three factors: the toxicity of the substance, the quantity of pollutant that can be released, and the likelihood of a hazardous event. However, each method considered those factors from a different approach.

The quantity of potential polluting substances discharged does not allow a direct relationship with their incidence as groundwater contaminants, and it is the subsurface mobility and persistence of contaminants that are the key factors (Foster et al., 2002). Overall, some correlation between the amounts of fertilisers used, the leaching rate, and the quantity of pollutants that reach groundwater, can be stated (Foster et al., 2002).

The $\mathrm{HI}$ introduces quantity $\left(Q_{n}\right)$ as a correction factor in the index calculation formula. The aim is to modify the harmfulness of anthropogenic activities based on the quantity of pollutant liable to be released. Nevertheless, according to the authors, the influence of this factor should not substantially deviate the weighting value assigned to a certain hazard (De Ketelaere et al., 2004). Therefore, the range of values proposed by this index prevent from obtaining a high or very high categorisation in activities with low toxicity, which can pollute groundwater if the flux is intensive but constant. Vías (2005) already mentioned this weakness and highlighted that the index could lead to fail in the representation of the real situation in the study area. In addition, the basis of the $\mathrm{HI}$ is mainly the toxicity of the pollutants instead of the quantity, so the variations related to this 
factor are usually irrelevant. This is evidenced by the fact that $30 \%$ and $43 \%$ of the listed sources, respectively, are able to increase or decrease its hazard level due to the $Q_{n}$ (Vías, 2005).

In the case of the $\mathrm{DCl}$, the index is based on the water consumption, the type of work, and the presence of refluents or refuses storage with high toxicity (Civita \& Di Maio, 1997), but it does not take into account the amount of those refluents. On the other hand, the POSH method considers quantities of pollutant substances used or discharged on its classification of points and diffuse sources of pollution. In the case of non-punctual sources, the amount and type of fertiliser is intrinsically related to the agricultural practices, which determines the hazard level. In urban sources, the ranking is based on the proportion of lands uncovered by sewerage systems and the population density, thus, the quantity of pollutants discharged are qualitatively considered in the categorisation of sources. Moreover, the point sources directly quantify the amount of hazardous chemicals substances used by industries for the hazard classification. It also indirectly estimates the amounts of pollutants in relation to the size of urban and industrial areas.

Apart from the quantity, another key aspect when assessing hazards is the estimation of the likelihood of occurrence of a hazardous event. Generally, the hazard level of a particular activity is related to the probability of groundwater pollution. However, this statement did not apply from the diffuse pollution perspective, which works as a low but constant source of pollution, i.e. the low hazard level of agriculture and urban activities do not involve low likelihood of groundwater pollution.

The $\mathrm{HI}$ considers likelihood of groundwater pollution as a reduction factor $\left(R_{f}\right)$ when assessing potential sources of contamination (De Ketelaere et al., 2004). This method follows a quantitative approach, and gives a likelihood value to each activity. The type of activity, the presence of protection and security measures, or the age of the facilities, determine the value of $R_{f}$, which is included in the $\mathrm{HI}$ calculation formula. Thus, in cases where $R_{f}$ is zero, it is considered that no risk of groundwater pollution exists, whereas if no information about such measures is known, $R_{f}$ is set to one, and no reduction of the potential impact to the groundwater occurs.

A large number of anthropogenic activities are potentially capable of generating a significant contaminant load, although only a few types are commonly responsible for the majority of the serious cases of groundwater pollution (Foster et al., 2002). From the $\mathrm{HI}$ approach, the quantitative determination of the probability of contamination is hard to achieve, and the estimation of the rate of reduction strongly differs from one activity to another. For instance, in the study area, probabilities of diffuse pollution from agricultural and urban sources are difficult to 
quantify, thus the value of $R_{f}$ was close to one in most of the potential sources, depending on the type of crop and the distance to the sewerage system, respectively. The type of crop, the quantity of fertilisers applied or the status of the sewerage system are useful indicators, although only small deviations from one are recommended to be applied in order to not underestimate hazards (De Ketelaere et al., 2004).

The DCI basically follows the rating system proposed by the USEPA (1978) and Mazurek (1979), but it also includes agricultural activities and diffused sources. This index considers that a probabilistic evaluation of the hazardous events cannot predict the frequency of future groundwater contamination (Ducci, 1999) and should not be applied to groundwater. In this manner, it omits both the inclusion of a correction factor as well as the qualitative consideration of probability during the weighting process. However, the DCl intrinsically considers the influence of the probability, since it recommends a reclassification at a lower hazard level when structural or non-structural measures are present.

In contrast to the $\mathrm{HI}$, the POSH method uses a qualitative approach, in which the likelihood is previously taken into account during the categorisation of anthropogenic activities. The POSH method characterises the potential sources of pollution on the basis of the likelihood of the presence of contaminants into groundwater, and its persistence and mobility (Foster et al., 2002). The likelihood is then associated with the type of anthropogenic activity and the estimated hydraulic surcharge based on the water use. In the case of agricultural activities, the probability of the presence of a contaminant load depends on the type of agricultural activity. Usually, more traditional crop rotations, extensive pasture or ecological farming present less probability of pollution than monoculture, irrigated or intensive cultivation. The categorisation of agricultural lands based on its potential to pollute groundwater systems generally depends on soil properties, rainfall or irrigation regimes, the type of crop and the quantity and variety of fertiliser and pesticide applied. In the study area, the POSH index includes irrigated areas in the high hazard level due to the intensive use of fertilisers and the irrigation management.

The estimation of the quantity and the likelihood factor in the study area depended on the available information and on the quality of the collected data. Table 3 and Table 4 list the sources in which $Q_{n}$ and $R_{f}$ have been modified. Following the instructions proposed by De Ketelaere et al. (2004), when no information was available, $Q_{n}$ has been set to 1.2 and $R_{f}$ has been set to 1 . Thus, the hazard estimation showed the maximum hazard potential. 


\subsection{Common challenges of hazard mapping and proposal for improvement}

The inventory and delimitation of the potential sources of pollution have had to deal with a traditional issue of the data spatial representation; this is the concurrent representation of punctual, linear and polygonal elements on a map (Pueyo et al., 2006). Bearing in mind that the objective was to obtain a comprehensive and easily legible map at a catchment scale, which could include all the potential hazards, the symbology has tried to represent different activities in a logical way. The hazards have been represented on the maps by means of symbols or patterns of different colour to indicate their potential degree of harmfulness. As a thematic map, the hazard maps show the distribution and location of different types of hazards.

Punctual symbols have been used to represent located but not innocuous hazards (e.g. factory farms, slurry storage tanks, waste water treatment plants, etc.), whose size cannot be presented in any other way but using this kind of symbols due to its small dimensions. On the other hand, extensive activities, usually related to sources of diffuse pollution as agricultural lands or urbanisation areas, have been presented by means of polygons of variable size.

The spatial representation of punctual symbols faces two main issues at the study area. First, at the regional scale, the size of the figures should be big enough to be easily observable, which usually means a lack of accuracy related to the precise location of the activity. Secondly, the overlapping of nearby points complicates the interpretation of the map. In general, punctual sources of pollution classified in the high or very high level are not properly perceived as dangerous by the general public due to the size of the symbols on the maps. In relation to this, it is not possible to visually compare between the relevance of the diffuse and the punctual pollution. Those semiotic and representation problems have not been solved by any method.

The accuracy of the map in relation to the distribution of the hazards is dependent on the quality of the original data and the scale of information (De Ketelaere et al., 2004). In the Gallocanta Basin, a high resolution scale was used to collect data, whereas the scale of the output map was regional. Consequently, the level of detail of the original data was higher than the resolution of the output map, so following the instructions given by Conrad et al. (2004), most of the local information should be adapted to the output scale, although this usually implies a loss of information or accuracy. Accurate and detailed data are essential when mapping hazards, since the correct delimitation of hazardous areas can make the difference in the case of the implementation of policies aimed to protect both the environment and human beings. In this study, punctual sources of pollution have been represented by means of polygons or punctual 
symbols in regional maps, but have been complemented with maps with larger scales where needed.

Finally, both the tendency of the homogeneity of the uses at the study area, the wide range of hazard degrees of the methods and the detailed comparative analysis of the indexes, allow us to observe conceptual limitations. Those limitations skew the results in two ways: firstly, they tend to make the hazard maps uniform, and secondly, they are prone to undervalue the hazard level of certain rural activities. Among the causes of those limitations, it can be highlighted the fact that the more harmful activities are given, the higher the hazard ranking, even though the hazardous event is less likely than constant pollution from low harmfulness activities in the long term. Consequently, non-point sources of pollution (e.g. agriculture) are systematically gathered in the moderate and low intervals, without taking into account consistent hazard levels related to the constant flux of pollution from diffuse activities compared to the eventual contamination from punctual sources. Another cause could be that the thresholds of the low, moderate and high hazard levels are not based on objective criteria. In theory, a division into regular intervals does not follow a proportional criterion between the interval classification and the existent pollution input of the activities.

After the application of the methods and the comparative analysis of the results, several proposals of improvements may be suggested in order to obtain better hazard maps. (1) It seems necessary to calibrate the ranking and setting the limits of the intervals by comparing the scores given to the activities and the collected pollution data of the area. The comparison would allow to improve the proportionality of the hazard level given by each method, and to avoid contradictions as those observed in the study area, where the theoretical hazard classification does not match with the highly polluted groundwater system. (2) It may be considered a change of the treatment to the diffuse pollution sources, especially in comparison to the punctual sources. The applied methods give more relevance to the theoretical harmfulness of a potential hazardous event than to the likelihood of occurrence of the event itself. Therefore, the potential pollution of non-punctual activities, such as agriculture, are underrated since their harmfulness is low but constant and sustained over time, which contribute to the accumulation of pollutants.

\section{Conclusions}

In this research, groundwater hazard mapping was performed by using $\mathrm{HI}, \mathrm{DCl}$ and $\mathrm{POSH}$ methods in the Gallocanta Basin (Spain). A comparison of the hazard maps was done to assess their effectiveness representing potential and existing sources of groundwater pollution, and the 
differences between methods were explored. The main issues of the hazard mapping process were related to the heterogeneity of the methodological approach and to the tendency of the methods to underestimate hazard degree in the Mediterranean area.

The results showed that the methods differed in the hazard categorisation of the Gallocanta Basin. The $\mathrm{HI}$ tended to classify most of the study area in the low hazard level, whereas the $\mathrm{DCl}$ and the POSH methods allowed to map sources with a higher hazard level. The variations in the hazard maps were due to differences in the weighting procedure, the categorisation of potential sources of pollution, and the influence of factors such as quantity or likelihood.

The methodologies were designed to be applied in different types of contexts so they consider a wide range of human activities. In comparison to agricultural and urban sources, which are indirectly related to the low hazard level, industrial activities are classified as the most pollutant sources. However, in the study area, agriculture and urbanisation are the dominant land uses. Although such uses have a lower toxicity than the industrial sources, they could eventually be as hazardous as industrial activities due to its characteristics (e.g. non-point sources, intensive agriculture and urbanisation, etc.).

In the light of the hazard maps, the hazard level of agricultural and livestock sources is generally underrated by the applied methods. This is corroborated by the fact that the GHU is partially affected by pollution from agricultural sources, and consequently declared as a NVZ for twenty years. In spite of this, they are classified as low or moderate sources of pollution. Therefore, underestimation of the hazard level may lead to the decision-makers to implement inappropriate measures committed to reduce the risk of groundwater pollution, and, therefore, to the inaccuracy of the programmes.

Acknowledgements: Financial support for this work was provided by the Spanish Ministry of Economy and Competitiveness via the Research Project AGRO-SOS (CGL2015-66016-R). This work could also be done thanks to a PhD fellowship granted by the Government of Aragon to José María Orellana (BOA 20/07/2017).

Authorship statement: The authors declare no conflict of interest. The participation of the authors in the article is as follows. José María Orellana: literature review, introduction, data collection, cartographic analysis, results and conclusions. María Jesús Perles Roselló: literature review, methodology and discussion. 


\section{References}

Andreo, B., Goldscheider, N., Vadillo, I., Vías, J. M., Neukum, C., Brechenmacher, J., \& Sinreich, M. (2004). Sierra de Líbar, Southern Spain. In F. Zwahlen (Ed.), Vulnerability and risk mapping for the protection of carbonate (karst) aquifers (COST action 620) (pp. 183-200). Brussels: European Commission, Directorate-General XII Science, Research and Development.

Boulabeiz, M., Klebingat, S., \& Agaguenia, S. (2019). A GIS-Based GOD Model and Hazard Index Analysis: The Quaternary Coastal Collo Aquifer (NE-Algeria). Groundwater, 57(1), 166176. https://doi.org/10.1111/gwat.12824

Burri, N. M., Weatherl, R., Moeck, C., \& Schirmer, M. (2019). A review of threats to groundwater quality in the anthropocene. Science of the Total Environment, 684, 136154. https://doi.org/10.1016/i.scitotenv.2019.05.236

Busico, G., Cuoco, E., Sirna, M., Mastrocicco, M., \& Tedesco, D. (2017). Aquifer vulnerability and potential risk assessment: application to an intensely cultivated and densely populated area in Southern Italy. Arabian Journal of Geosciences, 10(10), 125. https://doi.org/10.1007/s12517f017-2996-y

Cichocki, G., Zojer, H., \& Zojer, H. (2004). Comparative application of the new Austrian Approach (VURAAS) and the PI method of intrinsic vulnerability mapping, and hazard mapping. In F. Zwahlen (Ed.), Vulnerability and risk mapping for the protection of carbonate (karst) aquifers (COST action 620) (pp. 230-240). Brussels: European Commission, Directorate-General XII Science, Research and Development.

Civita, M. \& De Maio, M. (1997) Assessing groundwater contamination risk using ARC/INFO via GRID function. In Proceedings of ESRI Conference 1997. San Diego, July 8-11.

Confederación Hidrográfica del Ebro (2003). Establecimiento de las normas de explotación de la unidad hidrogeológica "Gallocanta" y delimitación de los perímetros de protección de la laguna de Gallocanta (Unpublished report).

Confederación Hidrográfica del Ebro (2016). Informe sobre la determinación de las aguas afectadas o en riesgo de contaminación por nitratos de origen agrario en la demarcación del Ebro. Periodo (2012-2015). Retrieved

from: http://www. chebro.es/contenido.visualizar. do?idContenido=19441\&idMenu=3811

Confederación Hidrográfica del Ebro (2019). SITEbro. In Confederación Hidrográfica del Ebro. Retrieved from http://iber.chebro.es/geoportal/ 
Conrad, J., Hughes, S., \& Weaver, J. (2004). Map production. In A. Zaporozec (Ed.), Groundwater contamination inventory. A methodological guide with a model legend for groundwater contamination inventory and risk maps (pp. 75-98). Paris: UNESCO.

Cosgrove, W. J., \& Rijsberman, F. R. (2000). World Water Vision: Making Water Everybody's Business. London: Earthscan Publications Ldt.

Daly, D., Hötzl, H., \& De Ketelaere, D. (2004). Risk Assessment. In F. Zwahlen (Ed.), Vulnerability and risk mapping for the protection of carbonate (karst) aquifers (COST action 620) (pp. 106-121). Brussels: European Commission, Directorate-General XII Science, Research and Development.

De Ketelaere, D., Hötzl, H., Neukum, C., Civita, M., \& Sappa, G. (2004). Hazard Analysis and Mapping. In F. Zwahlen (Ed.), Vulnerability and risk mapping for the protection of carbonate (karst) aquifers (COST action 620) (Vol. 1, pp. 86-105). Brussels: European Commission, Directorate-General XII Science, Research and Development.

Dimitriou, E., Karaouzas, I., Sarantakos, K., Zacharias, I., Bogdanos, K., \& Diapoulis, A. (2008). Groundwater risk assessment at a heavily industrialised catchment and the associated impacts on a peri-urban wetland. Journal of Environmental Management, 88(3), 526538. https://doi.org/10.1016/j.jenvman.2007.03.019

Ducci, D. (1999). GIS Techniques for Mapping Groundwater Contamination Risk. Natural Hazards, 20, 279-294. https://doi.org/10.1023/A

EASAC. (2010). Groundwater in the Southern Member States of the European Union. Halle: European Academies Science Advisoty Council.

Entezari, M., Yamani, M., \& Jafari Aghdam, M. (2016). Evaluation of intrinsic vulnerability, hazard and risk mapping for karst aquifers, Khorein aquifer, Kermanshah province: a case study. Environmental Earth Sciences, 75(5), 1-10. https://doi.org/10.1007/s12665-016-5258-5

ESRI (2011). ArcGIS Desktop: Release 10.5. Environmental Systems Research Institute, Redlands, California.

European Commission. (2018). Report on the implementation of Council Directive 91/676/EEC concerning the protection of waters against pollution caused by nitrates from agricultural sources based on Member State reports for the period 2012-2015. Retrieved from https://eurlex.europa.eu/legal-content/en/TXT/?uri=CELEX\%3A52018DC0257 
European Economic Community (EEC). Council Directive 91/271/EEC (1991a). Brussels, European Economic Community. Retrieved from https://eur-lex.europa.eu/legalcontent/EN/TXT/?uri=CELEX\%3A31991L0271

European Economic Community (EEC). Council Directive 91/676/EEC (1991b). Brussels, European Economic Community. Retrieved from https://eur-lex.europa.eu/legalcontent/es/ALL/?uri=CELEX\%3A31991L0676

European Economic Community (EEC). Council Directive 2000/60/EC (2000). Brussels, European Economic Community. Retrieved from https://eurlex.europa.eu/eli/dir/2000/60/oj

European Union (EU). Council Directive 2006/118/EC, 19 Official Journal of the European Union (2006). Retrieved from http://eur-lex.europa.eu/legalcontent/EN/TXT/?uri=CELEX:32006L0118

Foster, S., \& Hirata, R. (1988) Groundwater pollution risk assessment. A methodology using available data. Lima: Pan-American Center for Sanitary Engineering and Environmental Sciences (CEPIS).

Foster, S., \& Candela, L. (2007). Diffuse Groundwater Quality Impacts from Agricultural Landuse: Management and Policy Implications of Scientific Realities. In P. Quevauviller (Ed.), Groundwater Science and Policy. An international overview (pp. 454-470). London: Royal Society of Chemistry. https://doi.org/10.1039/9781847558039-00454

Foster, S., Hirata, R., Gomes, D., D’Elia, M., \& Paris, M. (2002). Groundwater Quality Protection (Groundwater Management Advisory Team, Ed.). Washington D.C.: The World Bank.

Foster, S. S. D., \& Chilton, P. J. (2003). Groundwater: The processes and global significance of aquifer degradation. Philosophical Transactions of the Royal Society B: Biological Sciences, 358(1440), 1957-1972. https://doi.org/10.1098/rstb.2003.1380

Gallagher, F. J., Pechmann, I., Bogden, J. D., Grabosky, J., \& Weis, P. (2008). Soil metal concentrations and vegetative assemblage structure in an urban brownfield. Environmental Pollution, 153(2), 351-361. https://doi.org/10.1016/j.envpol.2007.08.011

Gleeson, T., Wada, Y., Bierkens, M. F. P., \& Van Beek, L. P. H. (2012). Water balance of global aquifers revealed by groundwater footprint. Nature, 488(7410), 197200. https://doi.org/10.1038/nature11295 
Goverment of Aragón (1997). DECRETO 77/1997, de 27 de mayo, del Gobierno de Aragón, por el que se aprueba el Código de Buenas Prácticas Agrarias de la Comunidad Autónoma de Aragón y se designan determinadas áreas Zonas Vulnerables a la contaminación de las aguas por los nitratos procedentes de fuentes agrarias. Retrieved from http://www.boa.aragon.es/cgi$\underline{\mathrm{bin} / \mathrm{EBOA} / \mathrm{BRSCG} \text { ? CMD }=\mathrm{VEROBJ} \& M L K O B=437091763531}$

Goldscheider, N., Brechenmacher, J., Hötzl, H., \& Neukum, C. (2004). Comparative application of the German GLA method, the Swiss EPIK method and the PI method of intrinsic vulnerability mapping, and hazard mapping. In F. Zwahlen (Ed.), Vulnerability and risk mapping for the protection of carbonate (karst) aquifers (COST action 620) (pp. 200-217). Brussels: European Commission, Directorate-General XII Science, Research and Development.

Gracia, F.J., Gutiérrez, F., \& Gutiérrez, M. (1999). Evolución Geomorfológica del Polje de Gallocanta (Cordillera Ibérica). Revista de la Sociedad Geológica de España, 12(3-4), 351368.

Hamamin, D. F., Qadir, R. A., Ali, S. S., \& Bosch, A. P. (2018). Hazard and risk intensity maps for water-bearing units: a case study. International Journal of Environmental Science and Technology, 15(1), 173-184. https://doi.org/10.1007/s13762-017-1376-1

International Panel on Climate Change (IPCC) (2018). Special Report. Global warming of $1.5{ }^{\circ} \mathrm{C}$. Retrieved from https://www.ipcc.ch/sr15/

Jiménez-Madrid, A., Martínez-Navarrete, C., \& Carrasco-Cantos, F. (2010). Groundwater risk intensity assessment. Application to carbonate aquifers of the western mediterranean (Southern Spain). Geodinamica Acta, 23(1-3), 101-111. https://doi.org/10.3166/ga.23.101-111

Johansson, P., \& Hirata, R. (2004). Rating of groundwater contamination sources. In A. Zaporozec (Ed.), Groundwater contamination inventory. A methodological guide with a model legend for groundwater contamination inventory and risk maps (pp. 63-74). Paris: UNESCO.

Kuisi, M. Al, Mashal, K., Al-Qinna, M., Hamad, A. A., \& Margana, A. (2014). Groundwater Vulnerability and Hazard Mapping in an Arid Region: Case Study, Amman-Zarqa Basin (AZB)Jordan. Journal of Water Resource and Protection, 6(04), 297318. https://doi.org/10.4236/jwarp.2014.64033

Llamas, R., \& Custodio, E. (2002). Intensive use of groundwater. Challeges and opportunities. (R. Llamas \& E. Custodio, Eds.). Lisse: A.A. Balkema. 
Mádl-Szőnyi, J., Katalin, N., Mez

Q́,zitâgyHaVàsdszenty, A., \& Halupka, G. (2004).

Intrinsic vulnerability mapping using the "preliminary European Approach", and hazard mapping. In F. Zwahlen (Ed.), Vulnerability and risk mapping for the protection of carbonate (karst) aquifers (COST action 620) (pp. 274-286). Brussels: European Commission, DirectorateGeneral XII Science, Research and Development.

Mazurek, J. (1979). Summary of the Modified LeGrand Method. Norman: National Center for Groundwater Research.

Mimi, Z. A., \& Assi, A. (2009). Intrinsic vulnerability, hazard and risk mapping for karst aquifers: A case study. Journal of Hydrology, 364(3-4), 298310. https://doi.org/10.1016/j.jhydrol.2008.11.008

Moreno, J. M., Aguiló, E., Alonso, S., Álvarez-Cobelas, M., Anadón, R., Ballester, F., \& Zazo, C. (2005). Evaluacion Preliminar de los impactos en España por efecto del Cambio Climático. (U. M. Moreno, Ed.). Madrid: Ministerio de Medio Ambiente.

Pérez, A., Luzón, A., Roc, A. C., Soria, A. R., Mayayo, M. J., \& Sánchez, J. A. (2002). Sedimentary gacies distribution and genesis of a recent carbonate-rich saline lake: Gallocanta Lake, Iberian Chain, NE Spain. Sedimentary Geology, 148, 185202. https://doi.org/10.1016/S0037-0738(01)00217-2

Pal, P. (2017). Industrial Water Treatmen Process Technology. (K. McCombs, Ed.), Industrial Water Treatment Process Technology. Joe Hayton. https://doi.org/10.1016/b978-0-12-810391$\underline{3.00001-1}$

Pueyo Campos, A., Zúñiga Antón, M., Sebastián López, M., \& Sáez Romera, C. (2006). Posibilidades de análisis y representación espacio-temporal de la información demográfica municipal española en el periodo 1970-2005. In M. T. Camacho Olmedo, J. A. Cañete Pérez, \& J. J. Lara Valle (Eds.), El acceso a la información espacial y las nuevas tecnologías geográficas (pp. 409-425). Granada: Universidad de Granada.

Santucci, L., Carol, E., \& Tanjal, C. (2018). Industrial waste as a source of surface and groundwater pollution for more than half a century in a sector of the Río de la Plata coastal plain (Argentina). Chemosphere, 206, 727-735.

https://doi.org/10.1016/j.chemosphere.2018.05.084 
Shrestha, S., Semkuyu, D. J., \& Pandey, V. P. (2016). Assessment of groundwater vulnerability and risk to pollution in Kathmandu Valley, Nepal. Science of the Total Environment, 556, 2335. https://doi.org/10.1016/j.scitotenv.2016.03.021

Sutton, M. A., Howard, C. M., Erisman, J. W., Billen, G., Bleeker, A., Grennfelt, P., \& Grizzetti, B. (2011). The European Nitrogen Assessment: Sources, Effects and Policy Perspectives. New York: Cambridge University Press.

UNESCO (2015). The United Nations world water development report 2015: water for a sustainable world. UNESCO Publishing, Paris. Paris.

USEPA (1978). Surface Impoundments and their effects on ground-water quality in the United States. A preliminary survey.

Vargas Amelin, E. (2018). KINDRA's final conference. Brussels. Retrieved from: https://kindraproject.eu/final-conference/

Vías, J. M. (2005). Desarrollo metodológico para la estimación y cartografía del riesgo de contaminación de las aguas subterráneas mediante SIG. Aplicación en acuíferos del sur de España. Universidad de Málaga.

Wick, K., Heumesser, C., \& Schmid, E. (2012). Groundwater nitrate contamination: Factors and indicators. Journal of Environmental Management, 111, 178186. https://doi.org/10.1016/j.jenvman.2012.06.030

Worrall, F., Spencer, E., \& Burt, T. P. (2009). The effectiveness of nitrate vulnerable zones for limiting surface water nitrate concentrations. Journal of Hydrology, 370(1-4), 2128. https://doi.org/10.1016/j.jhydrol.2009.02.036

Zhang, H., Yang, R., Wang, Y., \& Ye, R. (2019). The evaluation and prediction of agriculturerelated nitrate contamination in groundwater in Chengdu Plain, southwestern China. Hydrogeology Journal, 27(2), 785-799. https://doi.org/10.1007/s10040-018-1886-z

Zwahlen, F., Goldscheider, N., \& Neale, S. (2004). Introduction. In F. Zwahlen (Ed.), Vulnerability and risk mapping for the protection of carbonate (karst) aquifers (pp. 1-4). 